\title{
Targeting Fertility and Female Participation Through the Income Tax
}

\author{
Ghazala Azmat* and Libertad González ${ }^{\dagger}$ \\ (Universitat Pompeu Fabra)
}

May 2009

\begin{abstract}
We evaluate the effect of a 2003 reform in the Spanish income tax on fertility and the employment of mothers with small children. The reform introduced a tax credit for working mothers with children under the age of three, while also increasing child deductions for all households with children. Theoretically, given the interplay of these two components, the expected effect of the reform is ambiguous on both outcomes. We find that the combined reforms significantly increased both fertility (by almost five percent) and the employment rate of mothers with children under three (by two percent). These effects were more pronounced among less-educated women. In addition, to disentangle the impact of the two reform components, we use an earlier reform that increased child deductions in 1999. We find that the child deductions affect mothers' employment negatively, which implies that the 2003 tax credit would have increased employment even more (up to five percent) in the absence of the change in child deductions.
\end{abstract}

Keywords: female labor force participation, fertility, family policy, tax credit, child subsidy JEL Classification: J22, J13, H31

\footnotetext{
* Ghazala Azmat (corresponding author): Department of Economics and Business, University Pompeu Fabra, Ramon Trias Fargas 25-27, 08005 Barcelona, Spain. Email: ghazala.azmat@upf.edu, Tel.: +34-93-542-1757, Fax: $+34-93-542-1766$.

${ }^{\dagger}$ Libertad González: Department of Economics and Business, University Pompeu Fabra, Ramon Trias Fargas 25-27, 08005 Barcelona, Spain. Email: libertad.gonzalez@upf.edu, Tel.: +34-93-542-2610, Fax: +34-93-542-1766.
} 


\section{Introduction}

Most OECD countries have experienced substantial increases in female labor-market participation over the past few decades, accompanied by a persistent decline in fertility rates. ${ }^{3}$ However, the striking feature of these stylized facts is the large cross-country disparity in the relationship between female participation and fertility. Traditionally, the cross-country correlation between fertility and female participation was negative (such that countries with high female participation tended to have low fertility, and vice versa). However, more recently, this pattern has been reversed (Ahn and Mira (2002)).

Spain is one of the countries with record low levels of fertility coupled with persistently low female participation rates. Table 1 shows that Spain has one of the lowest female employment rates in the OECD, at 45 percent in 2002, compared with, for example, 66 percent in the US and the UK, 67 percent in Canada and 73 percent in Sweden. Spain has also experienced a substantial decrease in fertility rates in recent decades (see De la Rica and Ferrero (2003)). Between 1976 and 1999, the fertility rate in Spain decreased from 2.70 children per woman to 1.07 . Table 1 shows that Spain has one of the lowest total fertility rates among the OECD countries, at 1.25 in 2002, compared, for example, with two in the US or 1.6 in the UK.

As a means of countering this dual problem, the Spanish government introduced some tax reforms in 2003 that addressed both, low female participation and low fertility. First, a reform in the income tax potentially encouraged fertility by substantially increasing child deductions. It substantially raised standard tax deductions for households with children (and it further increased them per additional child) and increased yearly supplements per child under the age of three from 300 to 1,200 euros. Second, mothers' participation was targeted through the introduction of a new tax-credit of 1,200 euros per year for mothers with children under the age of three, conditional on employment.

The objective of this paper is to understand the effectiveness of this policy change in increasing female employment and fertility. At first glance the two policy objectives seem conflicting. We might expect that if women are encouraged to work they will be less likely to have children (and vice versa). From a theoretical point of view, the simultaneity of the two reform components would lead to an ambiguous effect on both fertility and employment.

\footnotetext{
${ }^{3}$ Between 1970 and 1995, average female participation increased from 45 to 62 percent in OECD countries, while fertility fell from 2.4 to 1.6 children per woman.
} 
We first estimate the overall effect of the 2003 reform on both fertility and mothers' employment and find a strong positive effect on each. Second, we investigate the potential dampening effects on employment from targeting fertility simultaneously with participation. Using a 1999 reform, we are able to take advantage of significant changes in child deductions that took place in the absence of a tax-credit contingent on work. We use this earlier reform to estimate the effect of child deductions on employment and use it to proxy for the effect of the 2003 changes in child deductions. By removing this effect, we are able to estimate the employment effect of the tax-credit component of the 2003 policy.

Overall, we find that the policy had substantial effects on the employment (and participation) of mothers with children under the age of three, the target group. We estimate that their employment rate increased significantly, by almost one percentage point (a two-percent increase given the average employment rate of 47 percent), as a result of the reform. This effect was particularly pronounced in the low-education groups. This is in line with the results in SánchezMangas and Sánchez-Marcos (2008), who investigate the short-run participation effects of the 2003 Spanish tax credit.

We also find a significant effect of the 2003 reform on fertility. We estimate that the birth rate increased by about three births per 1,000 women as a result of the policy change, a fivepercent increase. Our results suggest that both of the reform components encouraged fertility. The effect is found to be more pronounced for younger, less-educated women with no previous children.

Finally, when we net out the potential dampening effect of increased child deductions on mothers' employment, we find that the increase in employment among mothers with young children would have been as high as 2.3 percentage points as a result of the tax credit (and in the absence of the accompanying child deductions), a five-percent effect.

The results from this paper highlight two important issues. First, the pursuit of both goals (increasing fertility and female participation) is potentially problematic. The dual problem is prevalent in many countries, and trying to target one without offsetting the other is challenging. Second, we find that in this specific setting, it appears that the particular combination of the tax credit contingent on work and the increase in child deductions was successful in the two dimensions, increasing both fertility and the participation of mothers with young children. 
There is a large and growing literature that analyzes the relationship between fertility decisions and female labor-market participation (see Mincer (1963) for an early key contribution). The simultaneity of these decisions has motivated a number of studies that estimate them jointly. The earlier studies followed a static approach that focused on completed births (Becker (1960)). More recently, the life-cycle approach has focused on using the timing and spacing of births over the lifetime span (Hotz and Miller (1988); Francesconi (2002) and Attanasio et al. (2008)). For the specific case of Spain, De la Rica and Ferrero (2003), GutierrezDomenech (2008) and Alba et al. (2009) are examples of recent studies that analyze the fertility and participation relationship.

In these studies, the observed negative relationship between fertility and female labor-force participation is typically said to result from two effects: (1) a direct negative effect that small children exert on the mothers' decision whether or not to participate (because they require their mothers' time); and (2) an indirect effect that emerges from the correlation of fertility with unobserved factors that drive female participation (i.e., preference for children).

Our goal is more specific than that of these studies: We are interested in understanding the effect of a tax reform on fertility and female participation, as well as the possible interactions of the different policy components. There is also a large literature on the effectiveness of tax-related policy reforms on either fertility (Whittington et al (1990); Whittington (1992); Baughman and Dickert-Conlin (2005); Milligan (2005); Laroque and Salanie (2005, 2008); Brewer et al. (2008)) or participation (Eissa and Leibman (1996); Meyer and Rosenbaum (2001); Blundell et al. (2005); Francesconi and Van der Klaaw (2007) and Sánchez-Mangas and Sánchez-Marcos (2008)). ${ }^{4}$ Like us, Sánchez-Mangas and Sánchez-Marcos (2008) focus on the Spanish tax reform of 2003. While they concentrate on short-run participation effects (including only two years postreform), we use a longer sample period to analyze the impact on both fertility and employment. In addition, we take advantage of an earlier tax reform to disentangle the effects of the two policy changes that took place at the same time in 2003.

More recently, there has been some interest in looking at the effect of policy reforms on both, fertility and employment. For example, Francesconi and Van der Klaaw (2007) analyze the effect of a tax-credit reform (contingent on employment in the household) in the UK on employment and, additionally, look to see if it had any further effect on fertility decisions. Our

\footnotetext{
${ }^{4}$ See Del Boca and Locatelli (2006) for a survey.
} 
analysis of the 2003 tax reform in Spain is, however, complicated by the fact that there are two simultaneous components targeting fertility and participation. In turn, there are direct and indirect effects from each component on the two decisions.

The remainder of the paper is organized as follows. Section 2 describes Spain's 2003 reforms in the income tax. We lay out some simple theoretical predictions for how this policy change could potentially affect female labor supply and fertility incentives. In this section, we also discuss the 1999 reform in child deductions. Section 3 introduces the data and methodology. We first present how we estimate the net effect of the 2003 reform on fertility and employment and then explain how we use the 1999 reform to help disentangle the (theoretically ambiguous) effects of the 2003 reform. Section 4 discusses the main results. The final section summarizes and discusses our findings.

\section{The Spanish Income-Tax Reforms}

In this section, we briefly describe the Spanish tax system and the main changes that have taken place in recent years. In particular, we focus on the potential effects of these reforms on fertility and female employment (Section 2.1). In Section 2.2, we outline a simple framework that highlights the different channels through which child deductions and a tax credit, conditional on mothers' employment, could affect both outcomes.

In light of this framework, in Section 2.3 we discuss the potential effects of the 2003 reform. We consider the different channels through which this reform could have affected employment and fertility. The expected effects are complicated by the fact that both components of the reform could potentially have affected both outcomes directly, but also through potentially conflicting indirect effects.

Finally, in Section 2.4 we describe the 1999 reform which also increased child deductions, but did not include the tax-credit component. We will exploit this earlier reform to disentangle the effect of the 2003 increases in deductions from the effect of the new tax credit.

\subsection{The Spanish income tax and recent reforms}

In the Spanish income-tax system, an individual's or household's tax liability is calculated by subtracting certain "reductions" from gross earnings and then applying the corresponding tax rate to each bracket of taxable income. The main reduction, the "personal" reduction, is universal, 
while the second reduction is a function of earnings, and the third, the "family deduction," is a function of the number and ages of the children. ${ }^{5}$ These child deductions were increased in both 1999 and in 2003, as shown in Table A1.

Before 1999, each child gave rise to a tax credit (unconditional on mothers' employment) of the specified amounts, increasing with the number of children. The tax credit implied that a certain amount was subtracted from the tax liability, after applying the corresponding rate to taxable income. Starting in 1999, the tax credits became deductions, such that the specified amounts were subtracted from taxable income before applying the corresponding tax rate. The amounts were also increased. The first and second child generated a 1,200 euros deduction each, while the third and later children generated deductions of 1,800 euros. Additionally, an extra 300 euros could be subtracted per child under the age of three, and 150 per child ages three to 16 .

The extent to which a given deduction translated into tax savings (i.e., the amount of the implied subsidy) depended on the (marginal) tax bracket that an individual was subject to. In 1999, there were six brackets, and the marginal tax rate ranged between 18 and 48 percent. In 2003, the number of brackets was reduced to five, and the marginal rates were reduced slightly, ranging between 15 and 45 percent.

In 2003, the child deductions were substantially increased to 1,400 euros for the first child, 1,500 for the second, 2,200 for the third and 2,300 for the fourth and subsequent children (see Table A1). The deduction per child under three was increased from 300 to 1,200 euros, and the 150 euro deduction for children aged three to 16 was eliminated.

In addition to the child deductions, a new tax credit was introduced in 2003, which was conditional on having a child under the age of three and on the mother being employed. This new tax credit was announced in April 2002 and widely publicized as a cash benefit for working mothers (since one could apply to receive it in monthly installments rather than at the end of the tax year).

Mothers of children under the age of three were eligible for a tax credit of 100 euros a month, conditional on being employed. This was equivalent to approximately one-third of monthly childcare payments. ${ }^{6}$ Eligibility required either 15 days of full-time employment or 20 days of

\footnotetext{
${ }^{5}$ For married couples, both joint and individual tax filing are possible. The reductions and tax scale are the same in both cases. This implies that two-earner households find it advantageous to file separately, while one-earner households benefit from joint filing.

${ }^{6}$ In a public day-care center.
} 
part-time employment during the month, provided that the hours were at least 50 percent of fulltime. Moreover, the tax credit could not exceed the woman's annual social security payroll taxes.

Table 2 shows the annual tax savings generated by the child deductions and the tax credit. The first panel computes the tax savings associated with the birth of a new child between 1998 and 2003, while the second panel compares the total tax savings generated by all children in the household as a function of maternal employment.

\subsection{A simple framework}

The 2003 reform had two components. It increased child deductions and introduced the new tax credit. Each component had the potential to affect fertility and female employment, both directly and indirectly. We outline a simple framework that summarizes the different channels at work.

The two outcomes of interest are fertility and employment, which we treat as binary. Let $K$ denote the decision to have a child in year $t$ and $E$ indicate the employment decision. A woman's fertility decision can be summarized in the following expression:

$$
K_{t}=F\left(X, D_{k}, C_{k e}, \underset{(+)}{(+)}, E_{t-1}\right)
$$

The fertility decision is a function of a woman's characteristics $X$, which include, for example, her age and the number and ages of her previous children. It is also a direct function of the child deductions, $D_{k}{ }^{7}$ Higher subsidies associated with the birth of a child may encourage fertility by increasing after-tax income in the event of a birth (thus decreasing the cost of children), which is indicated by the positive sign in parentheses. A tax credit that is conditional on having a small child and working $\left(C_{k e}\right)$ is also expected to increase the attractiveness of having a child. These are the "direct effects" of the two policy instruments. Finally, we expect that a stronger laborforce attachment (as proxied by $E_{t-1}$ ) would discourage fertility, given that the birth of a child entails a career interruption and potential future wage losses. This is indicated by the negative sign in parentheses.

In addition, a woman's decision to work can be summarized as follows:

$$
E_{t}=G\left(Z, \underset{(-)}{\left.D_{k}, C_{k e}, K_{t-1}\right)}\right.
$$

The (current) employment decision is potentially affected by individual characteristics $(Z)$ such as the woman's education level and age. It is also a function of the child deductions, $D_{k}$, and the

\footnotetext{
${ }^{7}$ Subscript $\mathrm{k}$ indicates that the subsidy is conditional on children.
} 
tax credit (which is conditional on having children and on working), $C_{k e}$. Since the child deductions are universal, such that they increase after-tax income for all women with children, independent of employment status, they may discourage participation through a standard income effect (thus the negative sign). On the other hand, since the tax credit increases disposable income only if the woman works, it is expected to encourage participation (among mothers), as indicated by the positive sign. Finally, motherhood is expected to affect employment negatively through increasing the value of staying at home, especially while the child is small (such that $K_{t-1}$ enters the function negatively).

So far, we have described the direct effects of the child deductions and the tax credit on employment and fertility. However, there are also potential indirect or "feedback" effects at play. The deductions have a direct positive effect on fertility, but they could indirectly affect employment if mothers are less likely than non-mothers to work (as suggested by the negative sign on $K$ in equation 2). By the same token, the positive direct effect of the tax credit on fertility could feedback negatively on participation.

In turn, the child deductions are expected to have a direct negative effect on employment, and this could indirectly encourage additional fertility if a lower labor-force attachment makes women more likely to have children, as suggested by the negative sign on $E$ in equation 1. Finally, the positive direct effect of the tax credit on participation could discourage mothers from having more children, by strengthening their labor force attachment.

Thus, the fact that both policy instruments potentially have direct and indirect effects on each outcome, together with their joint implementation in 2003, makes the identification of the different effects challenging, to say the least. We next discuss the specifics of the 2003 (and 1999) reform, using this framework to highlight their potential effects on fertility and employment.

\subsection{Potential effects of the 2003 reform}

Regarding the potential effects of the 2003 reform on fertility, Table 2 (panel i) shows the annual tax savings associated with the birth of a new child. The size of the subsidy is a function of the number of (previous) children and of the marginal tax rate that the family is subject to. For example, in 2003, a family earning 10,000 euros a year and having their first child would be subject to the lowest marginal tax rate (15 percent), and they would be entitled to a 1,400-euro 
child deduction, plus a 1,200-euro supplement (see Table A1). Consequently, the birth would lead to tax savings equal to $(1,400+1,200) * 0.15=390$. The rest of the amounts in Table 2 (panel i) are calculated similarly by applying the deduction amounts and the different tax brackets. $^{8}$

The 2003 reform, thus, increased the subsidy associated with the birth of a new child by an amount between 120 and 570 euros a year, depending on the number of children and the household income (see Table 2, panel i). In relative terms, the increase was higher for lowerincome households (around 1.5 percent for the lower-income group, compared with 0.8 percent for the high-income one). Moreover, these amounts were increased by 1,200 euros a year if the mother worked (via the tax credit). Thus, as suggested by equation 1, both components of the reform encouraged fertility directly.

Regarding participation in the workforce, Table 2 (panel ii) shows the total tax savings generated by the 2003 reform by employment status of the mother, number of children and marginal tax bracket. The total subsidy is calculated by adding the deductions corresponding to each child, then applying the tax rate, and finally adding the tax credit if applicable. The 2003 reform increased disposable income for all households with children, but more so for families in which the mother was employed. As shown in equation 2, the tax credit conditional on employment would increase the incentives to work for eligible women (mothers with children under the age of three). ${ }^{9}$ However, the income effect generated by the increased deductions would make all mothers less likely to work. ${ }^{10}$

Therefore, we expect that the 2003 tax credit would have increased employment among mothers of children under the age of three, relative to mothers of older children, but this increase may have been dampened to some extent by the increase in deductions.

As well as these direct effects, there were the indirect "feedback" effects. For instance, by increasing the labor-force attachment of mothers with young children, the 2003 tax credit could

\footnotetext{
${ }^{8}$ In 2003, low-bracket households (15 percent) were those making less than (approximately) 10,400 euros a year, while a household making 30,000 was an example of a middle-bracket case (28 percent), and high-bracket households ( 45 percent) make more than 51,000 (own calculations). The two remaining intermediate tax brackets were 24 and 40 percent.

${ }^{9}$ The tax credit could also affect hours of work conditional on employment, since in order to be eligible, a mother had to work hours equivalent to "half of full time." It is, however, hard to sign this effect. Women already working full-time could be induced to work fewer hours, while women working very few hours could increase them in order to become eligible. Finally, women induced to work by the reform could work "just enough" hours, reducing average hours of work.

${ }^{10}$ The income effect could also work to reduce the number of hours worked among employed women.
} 
have had an indirect negative effect on subsequent births, which would have affected fertility negatively among women with at least one child.

The following table summarizes the expected direct and indirect effects of the 2003 reform on fertility and female employment. Note that, once we take into account the indirect effects, the net effect of the reform is ambiguous on both outcomes.

\begin{tabular}{|c|c|c|c|c|}
\hline \multicolumn{5}{|c|}{2003 reform } \\
\hline & Component & Effect & Sign & Overall effect \\
\hline \multirow[t]{4}{*}{ Fertility } & Child & Direct & + & \multirow{4}{*}{ ? } \\
\hline & deductions & Indirect & + & \\
\hline & \multirow[t]{2}{*}{ Tax credit } & Direct & + & \\
\hline & & Indirect & - & \\
\hline \multirow[t]{4}{*}{ Employment } & Child & Direct & - & \multirow{4}{*}{$?$} \\
\hline & deductions & Indirect & - & \\
\hline & \multirow[t]{2}{*}{ Tax credit } & Direct & + & \\
\hline & & Indirect & - & \\
\hline
\end{tabular}

\subsection{Potential effects of the 1999 reform}

Given the potential difficulties involved in evaluating a policy in which there are simultaneous components with conflicting effects, we take advantage of the 1999 reform, which increased child deductions by a similar magnitude, in the absence of the tax credit.

The 1999 reform increased the subsidies associated with the birth of a new child by amounts varying between 60 and 700 euros a year, depending on the number of children and the tax bracket (see Table 2, panel i). The magnitude was higher for higher tax brackets, and lower for the second child. However, as a proportion of gross income, the magnitude of the increase in subsidies was approximately one percent for all tax brackets (and around 0.8 percent for the second child).

This increase in child subsidies is expected to have encouraged fertility directly by increasing the after-tax income in the event of a birth, as shown in equation 1.

The increase in deductions also had the potential to directly affect female labor-market participation. The child subsidies were universal, in the sense that they were not conditional on the mother's employment status. As shown in Table 2 (panel ii), the 1999 reform increased after- 
tax income for households with children by as much as 2,300 euros a year (for households with four children in the high tax bracket), independent of the mothers' labor-market status. The increase in disposable income was higher for larger families in higher tax brackets. ${ }^{11}$ This increase could have reduced participation among mothers through an income effect. ${ }^{12}$ Note that this channel could operate even if the increased deductions failed to increase fertility.

Thus, we expect the 1999 reform to have (directly) increased fertility and decreased participation among mothers. There are, however, additional indirect effects. If the increased child deductions managed to increase fertility, and mothers of young children worked less than other women, the reform would have indirectly depressed female employment rates, as suggested by equation 2. Moreover, the negative direct effect on participation could have indirectly boosted fertility further by lowering mothers' labor-force attachment. The table below summarizes the direct and indirect effects of the 1999 reform. Notice that in this case, the child deductions are expected to have unambiguously increased fertility and depressed labor-force participation.

\begin{tabular}{|c|c|c|c|c|}
\hline \multicolumn{5}{|c|}{1999 reform } \\
\hline & Component & Effect & Sign & Overall effect \\
\hline \multirow[t]{4}{*}{ Fertility } & Child & Direct & + & \multirow{4}{*}{+} \\
\hline & deductions & Indirect & + & \\
\hline & \multirow[t]{2}{*}{ Tax credit (NA) } & Direct & $\mathrm{n} / \mathrm{a}$ & \\
\hline & & Indirect & $\mathrm{n} / \mathrm{a}$ & \\
\hline \multirow[t]{4}{*}{ Employment } & \multirow{2}{*}{$\begin{array}{l}\text { Child } \\
\text { deductions }\end{array}$} & Direct & - & \multirow{4}{*}{ - } \\
\hline & & Indirect & - & \\
\hline & \multirow[t]{2}{*}{ Tax credit (NA) } & Direct & $\mathrm{n} / \mathrm{a}$ & \\
\hline & & Indirect & $\mathrm{n} / \mathrm{a}$ & \\
\hline
\end{tabular}

Our empirical strategy will tease out these direct and indirect employment and fertility effects. We first estimate the overall effect of the 2003 reform on both dimensions. Then, we use the 1999 reform to estimate the effect generated by the increase in deductions (as a function of number of children and the tax bracket), and we use those estimates to analyze the extent to

\footnotetext{
${ }^{11}$ In relative terms, the magnitude of the increase in disposable income ranged between 1.3 and 2.9 percent for lowbracket households (depending on number of children), between 1.1 and 3.7 percent for middle-bracket ones, and between 0.9 and 3.7 percent for high-bracket households.

${ }^{12}$ It could also have had a negative effect on hours worked (conditional on working).
} 
which the increased deductions dampened the employment effect generated by the 2003 tax credit. The details of our empirical methodology are presented in the next section.

\section{Data and Methodology}

We begin the section by describing the data and the main variables used in the analysis. We then present our proposed methodology for understanding the impact of the 2003 tax reform on fertility and employment.

\subsection{Data and descriptive statistics}

The empirical investigation is carried out using the Spanish Labor Force Survey (EPA). A quarterly cross-sectional dataset collected by the Spanish Statistical Office (INE), the EPA contains information on individuals, households and families. We pool data from the first quarter of 1992 until the last quarter of 2008 and restrict our attention to women of childbearing age (18 to 45 ) who co-reside with a partner. ${ }^{13}$ The resulting sample size is $1,321,523$.

In Spain, birth rates amongst single women are very low. During the period 1992-2008, the birth rate was around 66 annual births per 1,000 women with a partner, compared with only 4 births a year per 1,000 women without a co-residing partner. Moreover, partnership rates have barely changed during this period. Although cohabitation has become relatively more popular, the overall proportion of women living with a partner (including both married and cohabiting) has remained essentially constant in recent years (for example, it was 57 percent in 1992 and 56 percent in 2008). ${ }^{14}$

Before discussing the methodology, we provide a brief descriptive analysis of the trends in fertility and female employment and report some summary statistics of the main variables used in the analysis.

Figure 1 displays the birth rate (the main dependent variable in the fertility analysis) for the sample of married women aged 18 to 45 between 1992 and 2008 (all women and separately by

\footnotetext{
${ }^{13}$ Note that sometimes we refer to our sample as "married women," but cohabiting women are always included.

${ }^{14}$ Note that in some countries, such as the UK and the US, the structure of tax-credit polices gave single-parents more generous contributions. This may have generated an incentive for couples to remain unmarried, separate or divorce. This was, however, not the case in Spain, where both child deductions and the 2003 tax credit were independent of marital status; thus, concerns about changes in selection into partnership should not be strong.
} 
education level). ${ }^{15}$ Annual births declined from around 70 per 1,000 women in 1993 to fewer than 60 in 1997 and then increased slowly. Fertility increased more rapidly from 2002, reaching 76 by 2008 . Our birth-rate estimates closely match official statistics. ${ }^{16}$

Figures 2 and 3 show the employment and participation rates for mothers of children aged zero to two, mothers of children aged three to 16, and all women without children (or with children over the age of 16), respectively. Both participation and employment increased steadily during the whole period for the three groups. In 1992, the employment rate was around 30 percent for mothers with children under three, 35 percent for women with older children, and 47 percent for women without children. By 2008, there had been a remarkable increase in the employment rates for the three groups $(58,61$ and 74 percent, respectively).

Table 3 reports the summary statistics for the main variables used in the analysis. The first panel includes the full sample, while the remaining three focus on the sub-samples of women with children under three, mothers with children aged three to 16 , and women without children. Almost seven percent of the women in the sample gave birth during the 12 months prior to the survey. The average employment rate was 47.5 percent, while it was 61 percent for women without children. The average participation rate was almost 60 percent, implying that around 12 percent of women were unemployed.

In our sample, 20 percent of the women had a child under the age of three, while 80 percent had children under 17. The average number of children was 1.4. Mean age was almost 36 years, and 5.7 percent of the women in the sample were foreign-born. A high proportion of women in the sample (57 percent) had a high school degree, while 27 percent had no high school diploma and 16 percent graduated from college. Note that, in terms of characteristics (immigrant status, education and age), mothers with children under three are closer to non-mothers than to women with older children.

\subsection{Methodology}

\footnotetext{
${ }^{15}$ We construct a binary variable ("birth"), which indicates that a woman gave birth during the 12 months previous to the survey interview, from the survey information on ages of the children. "Birth" takes the value one if a woman has a child under the age of one at the date of the interview.

${ }^{16}$ From the Spanish Statistical Institute, we gathered official data on the annual number of births and the female population to construct annual birth rates. Our Labor Force Survey estimates are very similar to these figures, implying that we are capturing the same aggregate trends.
} 
To estimate the effect of the 2003 reform on fertility and female employment, we begin by using standard techniques that capture the overall or "net" response to the reform. However, as we highlighted in the previous section, there are likely to be interactions between the two components of the reform (the child deduction and the tax credit). In order to disentangle the effects of the two, we exploit the 1999 reform, that contained similar changes in the child deductions but no tax credit existed. We explain this procedure below.

\subsubsection{Fertility}

In order to evaluate the effect of the 2003 Spanish income-tax reform on fertility, we estimate the following linear probability equation for the likelihood of giving birth in year $t:{ }^{17}$

$$
\text { Birth }_{i t}=\alpha+X_{i t}^{\prime} \gamma+Z_{t}^{\prime} \beta+\delta \text { Post } 2002+\lambda_{t}+\varepsilon_{i t}
$$

where Birth takes value one if an individual $i$ gave birth during the 12 months preceding the interview and zero otherwise, and where Post2002 takes the value one starting with the first quarter of 2003, when the reform became effective. The vector $X$ includes other individual-level variables expected to be associated with fertility: age, age squared, age cubed, the number of children in different age brackets (1-2, 3-5, 6-11 and 12-16), a dummy for foreign-born, dummies for educational attainment (high school, university, and dropout as the omitted category) and interaction terms between age, age squared and age cubed and the education dummies. The vector $Z$ includes aggregate controls: quarterly linear and squared time trends, the aggregate unemployment rate for each quarter, average hourly wages, and average house prices. $^{18}$

The $\delta$ coefficient will capture any breaks in the fertility trend corresponding with the timing of the 2003 income-tax reform. We expect this coefficient to be positive in response to the reform since the direct effects of both the increase in child deductions and the tax credit are positive (see Section 2.3). ${ }^{19}$ Since the reform introduced different incentives for families of different sizes, additional specifications are estimated that allow the Post2002 coefficient to vary with the number of previous children.

\footnotetext{
${ }^{17}$ We use linear probability models in all specifications to make our estimation procedure comparable throughout. We have, however, replicated our analysis using probit models and find very similar results.

${ }^{18}$ The aggregate controls are obtained from the Spanish National Statistical Institute and the OECD.

${ }^{19}$ However, recall that there may have been a "feedback" effect on women with previous children if the tax credit encouraged participation and higher labor-force attachment discouraged additional fertility.
} 
In addition, we extend our analysis to include the 1999 tax reform. In additional specifications, we include a Post1998 dummy, to capture the fertility effect of the 1999 increase in child deductions. We expect an unequivocally positive effect of the 1999 reform on fertility (see Section 2.4).

By comparing the magnitudes of the 1999 and 2003 fertility effects, we can assess the extent to which the 2003 tax credit reinforced the effect of the child deductions (through a direct, positive effect on fertility, as explained in Section 2.3) or dampened it (through an indirect effect, given that the tax credit encouraged participation among mothers). Since the indirect effect did not operate for women without children, we expect the 2003 reform to have had an unambiguously stronger effect than the 1999 one for women with no previous children.

\subsubsection{Labor supply}

\section{Overall employment effect}

We first estimate the net effect of the 2003 reform on employment (and participation), and then extend our analysis to disentangle the effects of the increased child deductions from the tax credit.

To estimate the overall effect of the reform on employment, we take into account that the tax credit targeted only mothers with young children. This allows us to use the regression-based differences-in-differences approach commonly used in the literature to evaluate tax-credit programs (see Eissa and Leibman (1996); Blundell et al. (2005); Francesconi and Van der Klaaw (2007)).

Our "treatment group" is defined as women eligible for the tax credit - i.e., mothers of children under the age of three - and our "control group" is composed of all other women in the sample. ${ }^{20}$ We also use mothers of children aged three to 16 as an alternative control group. This control group has the advantage that the women may be somewhat more similar (perhaps unobservably). However, there is also the disadvantage that a substantial part of this control group was previously treated (e.g., a woman with a child aged three in 2004 would have been eligible, and so subject to treatment, the previous year). If there are spillover employment effects over time, we would expect our estimates of the reform's effects to be dampened when using this

\footnotetext{
${ }^{20}$ This is the control group commonly used in the literature; see, for example, Sánchez-Mangas and Sánchez-Marcos (2008).
} 
control group. Our preferred control group is, therefore, all other women. We estimate the following linear probability equation for employment: ${ }^{21}$

$$
\text { Emp }_{i t}=\beta_{1}+X_{i t} \beta_{2}+\left(\eta_{1}+\eta_{2} \text { Treat }_{i}\right) t+\beta_{3} \text { Treat }_{i}+\beta_{4}{\text { Post } 2002_{t}+\gamma\left(\text { Treat }^{*} \text { Post } 2002\right)}(4)
$$

where Emp is a dummy variable equal to one if a woman reports working (and zero otherwise). We also estimate this regression using labor-force participation as the dependent variable. Although the tax credit was conditional on employment, not on participation, the high prevailing female unemployment rates suggest potentially higher effects on participation than employment. $^{22}$

The vector of characteristics $X$ includes age, age squared, marital status, the number of children present in the household, educational level (high school dropout, high school graduate or college graduate) and immigrant status. We also include a quarterly linear time trend, which differs for the treatment and control groups, such that we can control for systematic differences in the behavior between the two groups over time. The time trends and the individual characteristics should control for differences between the treatment and control groups that affect the level of employment.

The Treat variable simply denotes a dummy variable that is equal to one if a woman was the mother of a child under the age of three, and zero otherwise. The unobservable differences between the treatment and control groups are expected to be captured here, and we would expect the coefficient $\beta_{3}$ to be negative if women with children under the age of three had a lower employment rate than the control group of women. The Post2002 variable is a dummy variable that is equal to one for any quarter starting in 2003 (i.e., after the tax credit was implemented). The coefficient $\beta_{4}$ reflects the change in employment for both the treatment and control groups after the policy was introduced.

Finally, we construct a variable that will capture the treatment effect by interacting the postpolicy variable, Post2002, with the indicator for women with children under the age of three, Treat. We are, therefore, explicitly testing that $\gamma$, the coefficient on the interaction term between Post2002 and Treat, is greater than zero.

\footnotetext{
${ }^{21}$ As with the fertility estimates, we also estimate the employment specifications using a probit model. In addition, we estimate the employment effects using propensity score matching. In both cases, our results remain very similar.

${ }^{22}$ The female unemployment rate in Spain is one of the highest amongst OECD countries. In 2003 it stood at 16 percent, whereas the OCED average was 7.2 percent (OECD Statistical Compendium).
} 


\section{Employment: Two-stage analysis}

In Section 2.3, we discussed the potential effects of each component of the 2003 reform. Overall, we predicted that the policy would have directly increased employment amongst women with young children. However, this effect may have been dampened by the increases in child deductions, which would have had the opposite effect on employment (both directly through an income effect and indirectly through the effect on fertility). In order to disentangle the two conflicting effects on employment, we take advantage of the 1999 reform, which increased child deductions but did not include the tax credit component of the 2003 reform.

We implement the following two-step procedure. In the first stage, we estimate the net effect of the 1999 reform on employment, as a function of the magnitude of the subsidies implied by the increases in child deductions. We calculate these deductions for each of the different tax brackets, which pertain to different households depending on their income level. Since the size of the subsidy also depends on the number of children, we allow for those differences. See Table 2 for the actual amounts of the 1999 and 2003 increases in child deductions by number of children and tax bracket. ${ }^{23}$ We use the period 1992-2002 (i.e., the "pre-2003" policy period) and estimate the following linear probability model, where the reference category is married women with no children:

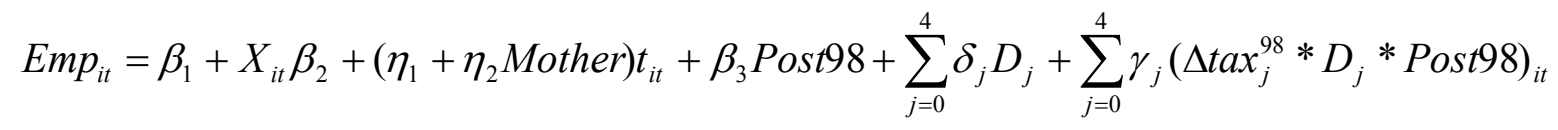

where $D_{j}$ are dummy variables for having $j$ children $(j=0, \ldots, 4$ (or more)). Here, $\Delta \operatorname{tax} 98$ represents the change in tax gains resulting from the 1999 reform. This amount changes depending on number of children, and there is a supplement for children under the age of three. Post98 is a dummy that takes value one starting with the first quarter of 1999. The coefficients $\gamma_{j}$ estimate

\footnotetext{
${ }^{23}$ Although the 1998 and 2003 policies are comparable in that the tax savings differ depending on the tax bracket (since they are implemented as deductions), before 1998, the child subsidies were implemented through a tax credit. Thus, in order to compute the change in tax savings from 1998 to 1999, we need to use the "average" tax saving (as in, for example, Whittington et al. (1990)). We do so by using the savings experienced by households in the intermediate tax bracket (28 percent). However, we also run additional specifications where we use different tax brackets as robustness checks. The results remain consistent.
} 
the effect of the 1999 reform in child deductions on employment, for an individual with $j$ children. $^{24}$

In the second stage, we want to estimate the employment effect of the 2003 tax credit without the effect coming from the child deductions. In order to do so, we use the estimated coefficients $\hat{\gamma}_{j}$ from the first stage to "proxy" the employment effects of the 2003 reform coming from increases in child deductions. The necessary assumption is that the employment effect of the child deductions for a given household type is linear in the monetary amount of the subsidy. Ultimately, we want to remove this effect in order to capture the "true" direct effect of the 2003 tax credit on employment.

We implement this second stage using a linear probability model, where the dependent variable takes different values depending on the ages and number of children. We use data from 2000 to 2008 (such that we do not include the 1999 policy change):

$$
\begin{aligned}
& \operatorname{Emp}_{i t}-\sum_{j=0}^{4} \hat{\gamma}_{j}\left(\Delta \operatorname{tax}_{j}^{03} * D_{j}^{*} \text { Post } 2002_{i t}\right. \\
& \left.=\beta_{1}+X_{i t} \beta_{2}+\left(\eta_{1}+\eta_{2} \text { Treat }_{i}\right) t+\sum_{j=0}^{4} \mu_{j} D_{j}+\mu_{5} \text { Treat }_{i}+\mu_{6}{\text { Post } 2002+\lambda\left(\text { Treat }^{*} \text { Post } 2002\right)}^{\text {Pon }}\right)
\end{aligned}
$$

Note that this is the same as equation 4, except that the dependent variable is adjusted to take into account the effect of the child deductions. Coefficient $\lambda$ will now give us the estimated effect of the 2003 reform, as if there had been no changes in the child deductions.

\section{Hours of work}

Since the 2003 (and 1999) reform could have affected not only employment and participation, but also hours of work (conditional on working), as mentioned in Section 2, we also estimate equation 4 using weekly hours worked as an additional dependent variable.

\section{Results}

In this section, we identify the effects of the 2003 tax reform on fertility and employment by describing the results from estimating the econometric specifications introduced in section 3.

\footnotetext{
${ }^{24}$ Note that in this specification, the "treated" group is composed of all mothers, since the deductions are conditional on having children.
} 
Tables 4 and 5 report the main results for the fertility analysis, while Tables 6 to 8 report the employment and participation results.

\subsection{Fertility}

Each row of Table 4 reports the results from a different specification of equation 3 . The first three rows analyze only the 2003 reform, while rows four and five also consider the 1999 reform. The first column of the table shows the average value of the dependent variable (an indicator for having given birth over the previous 12 months).

\subsubsection{Overall effect of the 2003 reform}

The first row of Table 4 does not include the linear or the squared time trends as controls. This specification suggests that the 2003 reform increased fertility significantly, by 7.5 births per 1,000 women. Since the average birth rate is 66 (per 1,000), this is an approximate increase of 11 percent. When we include the linear trend, the estimated effect goes up to 12 percent.

Figure 1, which reports the time-series changes in the annual birth rate, suggests that a second-order polynomial may better approximate the long-term trend in fertility. The estimated effect of the 2003 reform on fertility remains significant once we include the squared trend, and its magnitude is reduced to about three births per 1,000 women, almost a five-percent effect. This is our preferred specification and, overall, we conclude that the 2003 tax reform was associated with a significant increase in fertility.

Table A2 reports the coefficients on all of the control variables for the preferred specification. A birth is more likely among women without previous children. The probability of giving birth increases with age, although at a decreasing rate. A birth is less likely among younger, more-educated women, but becomes more likely as the woman gets older. In terms of the macro variables, a higher unemployment rate is associated with fewer births, and so are lower house prices and higher wages.

It is useful to compare the magnitude of our results to those found in previous studies. With US data, Whittington et al. (1990) use a long time series dataset (1913-1984) and find that changes in the child-dependent personal tax exemptions had a significant positive effect on fertility. They find that an increase of 50 dollars in the exemption (about 357 dollars in 2000 
terms) increased the general fertility rate by six to 12 births per 1,000 women. Whittington (1992) finds similar results when using the Panel Survey of Income Dynamics (1979-1983).

Laroque and Salanie (2008) use French data and find that an unconditional child subsidy of 150 euros a month (1,800 euros per year) in 1998 increased fertility by about 14 percent. In their previous paper, Laroque and Salanie (2005) estimated that a child benefit of 500 euros a month (6,000 euros per year) increased fertility by 24 percent, using French data for 1999. Milligan (2005), however, finds larger effects. He studies the effect of the Allowance for Newborn Children in Canada in 1998 and finds that a universal child subsidy of 1,000 Canadian dollars a year (about 624 euros) increased fertility by 17 percent.

Our results are smaller in magnitude than those found by Whittington et al. (1990) and Milligan (2005), since we find that an increase in (annual) child subsidies of about 350 euros (for the middle tax bracket), accompanied by a 1,200-euro tax credit conditional on work, increased fertility by three to four births per 1,000 women (about five percent).

\subsubsection{Comparing the 1999 and 2003 reforms}

Next, we analyze the effect of the 1999 reform on fertility. The fourth row of Table 4 reports the results of a specification that estimates the effect of the 1999 reform on fertility using a restricted sample that includes only the years prior to the 2003 reform (1992 to 2002). The 1999 increase in child deductions is estimated to have significantly increased fertility, by 4.5 percent. The point estimate is only slightly smaller in size than that of the 2003 reform (third row).

When we include both reforms into the same specification (fifth row), the marginal effect of the 1999 reform falls from 29 births per 1,000 women to 21 (a three-percent increase in fertility). This effect is smaller but remains marginally significant. ${ }^{25}$ Meanwhile, the estimated effect of the 2003 reform remains somewhat higher, at 5.5 percent. Although the increases in the child deductions were similar in both reforms, the 2003 reform may have had an additional positive effect on fertility through the sizeable tax credit for working mothers (see Section 2.3). ${ }^{26}$ However, note that we cannot reject the hypothesis that the effects of the two reforms are the same (p-value 0.287).

\footnotetext{
${ }^{25}$ The significance level is 11.8 percent.

${ }^{26}$ This is in line with what has been found in the literature. For example, Brewer et al. (2008) and Francesconi and van der Klauuw (2007) find that the Working Families' Tax Credit in the UK, a tax credit contingent on working, had a positive fertility effect, especially amongst married couples.
} 
Our analysis of the 1999 reform, which increased universal child subsidies, suggests that an increase in the subsidy associated with a new birth of about 250 euros a year increased fertility by three to four percent on average. This effect is close in magnitude to the estimates by Laroque and Salanie (2008), who predict that a child benefit of the same size would increase fertility by about two percent, on average. The estimates provided by Milligan (2005), on the other hand, would predict an effect of about 6.8 percent. Thus, we find fertility effects whose magnitude lies within the range of previous estimates reported in the literature.

Finally, Table 5 explores the effects of the 1999 and 2003 reforms on different subgroups of women. In particular, we may expect the effect to vary with the number of children and with household income. Since income is not observed in the survey, we estimate the effects of the reform by education level and age. The results suggest that both reforms had a stronger fertility effect on lower-educated mothers. The effect of both reforms on fertility for high school dropouts was significant, at 12 percent for the 1999 reform and nine percent for the 2003 reform. The effect is also more pronounced among younger women under both reforms. The 1999 reform increased fertility significantly, by 8.5 percent among women up to age 30 , while the 2003 effect was almost seven percent for the same group. This suggests that the fertility effects were mostly driven by low-income households.

The bottom panel of Table 5 shows the results by number of (previous) children. The 2003 reform did not generate sizeable differences in the subsidy associated with the birth of a new child depending on the number of other children. However, if the tax credit affected employment among women with young children (as we show in the next section), then this increase in laborforce attachment may have indirectly discouraged fertility among women with previous children. What we find, in fact, is that the 2003 reform increased fertility mostly among women with no previous children, with insignificant effects on women with previous children. Our interpretation is supported by the finding that the 1999 reform, which included no tax-credit component, had no significant effect on women with no previous children. The tax credit, thus, reinforced the fertility effect of the child deductions for women without children, as expected.

To sum up, in this section, we show that the 2003 reform significantly increased fertility (by about five percent, on average) and that the effect was driven mostly by younger, low-educated women with no previous children. The 1999 reform had a slightly smaller effect, which was also higher among low-educated women and younger women. 


\subsection{Labor supply}

\subsubsection{Employment}

Table 6 shows the main employment and participation results, derived from estimating equation 4. Each column reports the results from a different specification. The first two columns use the full sample of all married women, while the last two restrict the sample to married women with children under the age of 17.

The coefficient of interest is reported in the first row. It measures the effect of the 2003 reform on employment for mothers eligible for the tax credit, relative to those not eligible. The second row reports the coefficient on the treatment variable, which is the indicator for the presence of children under the age of three, and the third row reports the coefficient on the post2002 dummy.

The first specification shows that women with children under three are less likely to work than other women, and that female employment increased (overall) after 2002. The linear trend is also significantly positive, although less so for mothers with young children. ${ }^{27}$ The interaction term shows that mothers eligible for the tax credit were 0.88 points more likely to work after the reform, relative to other women. Since the average employment rate was 0.475 (see Table 3 ), the magnitude of the estimated effect is almost two percent. The effect on participation is also significant and larger in magnitude, suggesting that the tax credit increased employment but also induced some unemployment.

The magnitude and significance of the estimated effects are reduced when we restrict the sample to all mothers (i.e., the control group now includes only mothers with children aged three to 16). The tax credit is estimated to increase employment by 0.26 percentage points (not significant) and participation by 0.91 points. This is the likely consequence of a spillover effect onto the control group. ${ }^{28}$

Sánchez-Mangas and Sánchez-Marcos (2008) estimate the short-term effect of the 2003 reform on participation, focusing on the two years following the reform. They find that the tax credit increased participation among women with children under the age of three by almost three

\footnotetext{
${ }^{27}$ Figures 2 and 3 suggest that a linear trend should appropriately capture the long-term trend in employment and participation.

${ }^{28}$ Given that the reform was implemented in 2003 and our data go up to 2008, in 2008, mothers with children aged three to eight had been eligible for the tax credit in previous years.
} 
percentage points. Our estimates are smaller in magnitude, with a 1.3 percentage-point effect on participation. This suggests that the short-term effect of the reform was larger than the long-term one, given that our analysis includes six years after the tax credit was implemented. This is confirmed when we restrict the data to fewer post-reform years (not reported). ${ }^{29}$

Table 7 reports the employment and participation effects for different subgroups, defined by educational attainment, age and number of children. Since the size of the tax credit was independent of earnings, we would expect it to have increased employment more among lowerincome women, for whom the relative size of the subsidy was higher (and whose baseline employment rate was lower). Overall, we find the employment effect to be much stronger for less-educated, younger women. The reform increased employment by more than seven percent among women without a high school degree and by almost five percent among younger women.

We do not find significant effects on employment once we restrict the sample to families with a given number of children, although the magnitude of the estimated employment effects increases with the number of children. The participation regressions suggest that the effects were strongest for families with two or three children.

As a robustness check, we replicate our baseline estimation using propensity score matching methods. The results are presented in Table A6. Although we use fewer years, the effects remain strong and significant.

\subsubsection{Employment: two-stage procedure}

So far, we have estimated the effect of the 2003 tax reform on employment without taking into account the separate effects from each of the two reform components. We now turn to the twostage procedure described in Section 3.2.2, which allows us to disentangle the effect of the tax credit and increased child deductions on employment.

We first estimate an employment regression using only the pre-2003 period, in order to capture the effect of the 1999 increases in child deductions on mothers' employment. Panel A of Table 8 reports the results. ${ }^{30}$ To provide a sense of the overall magnitude of the 1999 reform on employment, we first report the results from a specification that uses only a post-1998 indicator

\footnotetext{
${ }^{29}$ We do report propensity score matching estimates in Table A6, for the restricted sample 2001-2005, and here we see larger estimates than those for the longer sample.

${ }^{30} \mathrm{We}$ report the results using the middle tax bracket. The results when using the other tax brackets are shown in Table A4.
} 
interacted with mothers, without the monetary amounts of the 1999 deductions. We find that the 1999 increases in child deductions reduced mothers' employment by 1.3 percentage points, on average. This is consistent with the expected effects discussed in Section 2.4.

In the second column, we report the results from estimating equation 5. Here, we include separate indicators of post-1998 interacted with the number of children and the monetary amounts of the child deduction increases corresponding to each family type. The magnitude of the deductions can be found in Tables 2 and A1. We find that the estimated effects are negative for all types of households, although both magnitude and significance are low for women with only one child.

We replicate the analysis for participation and find similar effects. The results, presented in columns three and four, show that the 1999 child deductions led to a decrease in mothers' laborforce participation by about 1.2 percentage points, and the effect was negative for all family sizes.

In the second stage, we take the estimated coefficients on the interaction terms and use them to estimate equation 6. This provides us with an estimate for the effect of the 2003 tax credit, in the absence of the accompanying increases in child deductions. The results from this second stage are reported in Panel B of Table 8.

We report both the employment and participation results. The first column shows the results from the two-step estimation procedure. ${ }^{31}$ The second column reports the main results from equation 4 (already shown in Table 5), for the sake of comparison. The third column re-estimates equation 4 using the restricted sample, 2000-2008.

By estimating equation 4, we found that the overall effect of the 2003 reform on the employment of mothers with children under three was 0.9 percentage points (1.68 if we restrict the sample to the years 2000 to 2008). However, our two-stage analysis suggests that, if the child deductions had not been raised in 2003, the tax credit would have increased employment by a significant 2.3 percent. This is a considerably larger effect that is dampened by the contemporaneous increases in deductions, which translates into a five-percent increase in employment (compared with the two-percent net effect).

\footnotetext{
${ }^{31}$ Panel B of Table 8 does not report the second stage for the specification shown in the first column of panel A due to space considerations, but the corresponding second-stage estimate for employment is a significant 2.1 points.
} 
We find quantitatively similar results when we look at participation. The overall effect of 1.3 percentage points (also 1.3 when we restrict the sample to the $2000-2008$ period) increases to 2.1 percentage points when we net out the effect of the increased deductions. ${ }^{32}$

To summarize, we find that the 2003 reform, which increased child deductions and introduced a tax credit for working mothers, significantly increased employment among mothers eligible for the tax credit (by around two percent, on average). However, we also find that this effect would have been even larger in the absence of the accompanying child deductions, which tended to discourage employment among mothers.

\subsubsection{Hours of work}

Since the 2003 reform may have affected not only employment and participation, but also hours of work, we report the results of estimating equation 4 using hours of work (conditional on working) as an additional dependent variable. These specifications are reported in Table A5. Each column shows the results from a different specification. The first two columns use all women without children under the age of three as the control group, while columns 3 and 4 restrict the sample to mothers of children under the age of 17 . We use two alternative dependent variables: usual weekly hours worked, and actual hours worked last week.

The findings suggest that women with children under the age of three reduced their hours of work after the 2003 reform by between 0.4 and 0.7 hours a week. The effects are strongly significant in all specifications. Given that average weekly hours in the sample were around 35, the results amount to a one- to two-percent reduction in hours as a result of the tax credit. This suggests that the hours requirement of the tax credit significantly affected labor supply, not only in the extensive margin, such that women adjusted their hours around the minimum level required. Alternatively, the results are also consistent with the explanation that the tax credit induced some mothers to work, but they worked fewer hours than the average (for instance, the reform may have induced mothers to work part-time), thus changing the composition of employed women. This is supported by the fact that the strongest effects on employment were on low-educated women, who tend to work fewer hours. ${ }^{33}$ These results imply that the effectiveness

\footnotetext{
${ }^{32}$ The estimated effect is a significant 1.6 points in the second stage corresponding to the third column of panel A.

${ }^{33}$ For example, in our full sample, 29 percent of women without a high-school degree worked fewer than 35 hours a week, compared with 24 percent of women with at least a high-school degree.
} 
of the 2003 reform in raising female employment was somewhat dampened by the accompanying fall in hours of work.

\section{Conclusions}

We evaluate the effect of a 2003 reform in the Spanish income tax on fertility and the employment of mothers with small children. The reform increased child deductions (essentially equivalent to universal child subsidies) and introduced a new tax credit for working mothers with children under the age of three (1,200 euros a year for three years).

Theoretically, because of the two components, the effect of the reform is ambiguous on both outcomes. The tax credit targets employment directly but has the potential to depress fertility, and the child deductions could encourage fertility but may discourage employment among mothers.

We find that the reform increased fertility significantly, by almost five percent. The effect was particularly pronounced (seven percent) among women without (previous) children. Since we do not observe a significant effect on the fertility of women with previous children, we conclude that the employment effect of the tax credit indirectly dampened the fertility effect among these women, by increasing their labor-force attachment. We also find that the tax credit increased employment by about five percent among women with very young children. This effect was dampened to two percent by the simultaneous increases in the child deductions. In addition, we find that the number of hours worked by mothers fell by one to two percent.

Our findings suggest that the tax credit was very effective at increasing employment, in particular amongst low-educated mothers. The increase in employment, given the small payment amount, is impressive when compared with other countries implementing similar policies, such as the US and UK. One explanation could be that, since the tax credit was a cash payment, equivalent to almost one third of (public) childcare costs, and it was paid directly to mothers, it targeted well low-educated (low-income) women.

Overall, we find that increasing child deductions may be an effective way of encouraging fecundity, although at the expense of discouraging participation. The tax credit, on the other hand, reinforced the fertility effect of the child deductions, while at the same time raising employment among mothers. Thus, we conclude that a tax credit for mothers conditional on 
work may be an effective way of targeting both policy goals, overcoming some of the trade-offs involved in alternative policy designs, such as universal child subsidies. 


\section{References}

Alba, A., Alvarez, G. and Carrasco, R. On the estimation of the effect of labour participation on fertility. Spanish Economic Review 2009; Vol.11, 1-22.

Ahn, N. and Mira P. A note of the relationship between fertility and female employment rates in developed countries. Journal of the Population Economics 2002; Vol.15, 667-682.

Attanasio, O., Low, H. and Sánchez -Marcos, V. Explaining Changes in Female Labor Supply in a Life-Cycle Model. American Economic Review 2008; Vol. 98, 1517-1552.

Baughman, R, and Dickert-Conlin, S. Did Expanding the EITC Promote Motherhood? American Economic Review Papers and Proceedings 2005; Vol. 93, 247-250.

Becker, G. An Economic Analysis of Fertility. In: Demographic and Economic Change in Developed Countries. Universities-National Bureau of Economic Research Conference 1960, 209-231.

Blundell, R., Brewer M. and Shephard A. Evaluating the Labour Market Impact of Working Families Tax Credit using Difference-in-Differences 2005; HM Revenue and Customs.

Brewer, M., Ratcliffe, A. and Smith, S. Does Welfare Reform Affect Fertility? Evidence from the UK. Institute of Fiscal Studies WP 08/09. 2008.

Carrasco, R. Binary Choice with Binary Endogenous Regressors in Panel Data: The Effect of Fertility on Female Labour Force Participation. Journal of Business and Economics Statistics 2001; Vol.19, 385-394.

Del Boca, D. and Locatelli M. The Determinants of Motherhood and Work: A Survey. IZA Discussion Paper 2006; No. 2414.

De la Rica, S. and Ferrero M. D. The Effect of Fertility on Labour Force Participation: The Spanish Evidence. Spanish Economic Review 2003; Vol. 5, 153-172.

Eissa, N. and Leibman J. B. Labour Supply Response to the Earned Income Tax Credit. The Quarterly Journal of Economics 1996; Vol 111, 605-637.

Francesconi, M. A Joint Dynamic Model of Fertility and Work of Married Women. Journal of Labor Economics 1992; Vol. 20, 336-380.

Francesconi, M. and Van der Klaaw W. The Socioeconomic Consequences of 'In-Work' Benefit Reform for British Lone Mothers. Journal of Human Resources 2007; Vol. 42, 1-31.

Guiterrez-Domenech, M. The Impact of Labour Market on the Timing of Marriage and Births in Spain. Journal of Population Economics 2008; Vol. 21, 83-110. 
Hotz, V.J. and Miller, R. A. An Empirical Analysis of Life Cycle Fertility and Female Labor Supply. Econometrica 1988; Vol. 56, 91-118.

Laroque, G., and Salanie, B. Fertility and Financial Incentives in France. CEPR Discussion Papers 5007. 2005.

Laroque, G., and Salanie, B. Does Fertility Respond to Financial Incentives? CESifo Working Paper 2339. 2008.

Meyer, B. D. and Rosenbaum, D. T. Welfare, The Earned Income Tax Credit, And The Labor Supply Of Single Mothers. The Quarterly Journal of Economics, 2001; Vol. 116, 1063-1114.

Mincer, J. Market Prices, Opportunity Cost and Income Effects. In: C.F. Christ, Editor, Market prices, opportunity costs and income effects, Stanford University Press 1963.

Milligan, K. Subsidizing the Stork: New Evidence on Tax Incentives and Fertility. Review of Economics and Statistics 2005; Vol. 87, 539-555.

Sánchez-Mangas, R. and Sánchez-Marcos, V. Balancing Family and Work: The Effect of Cash Benefits for Working Mothers. Labour Economics 2008; Vol. 15, 1127-1142.

Whittington, L. A, Alm, J. and Peters, H. E. Fertility and the Personal Exemption: Implicit Pronatalist Policy in the United States. American Economic Review 1990; Vol. 80, 545-556.

Whittington, L. A. Taxes and the family: The Impact of the Tax Exemption for Dependents on Marital Fertility. Demography 1992; Vol.29, 215-226. 


\section{Figures and tables}

Figure 1. Quarterly birth rates by education, 1992-2008

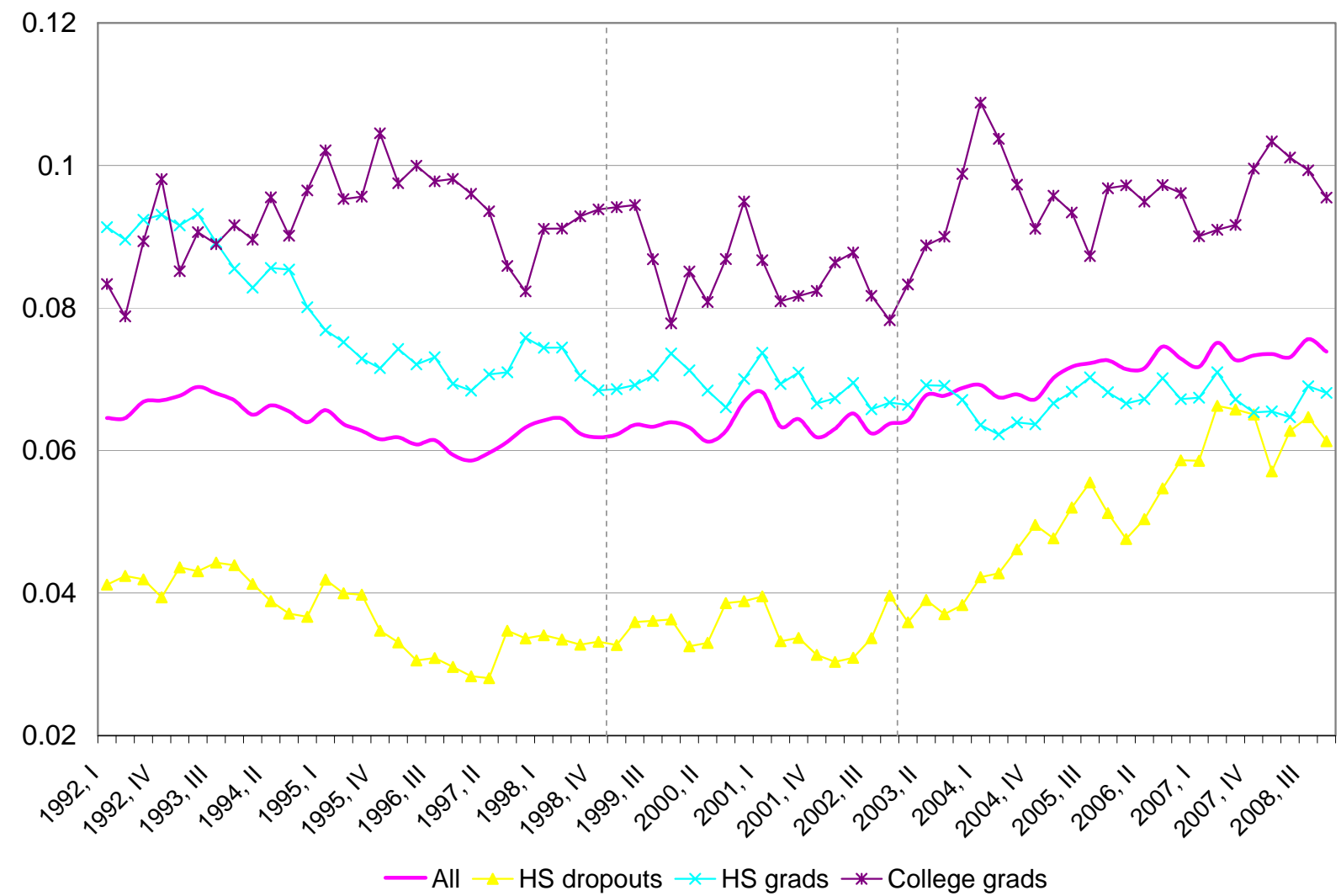

Source: Spanish Labor Force Survey (EPA) 1992-2008.

Note: Annual birth rates are defined as the proportion of women aged 18 to 45 who gave birth during the 12 months previous to the interview. The data are quarterly. 
Figure 2. Employment rates, 1992-2008

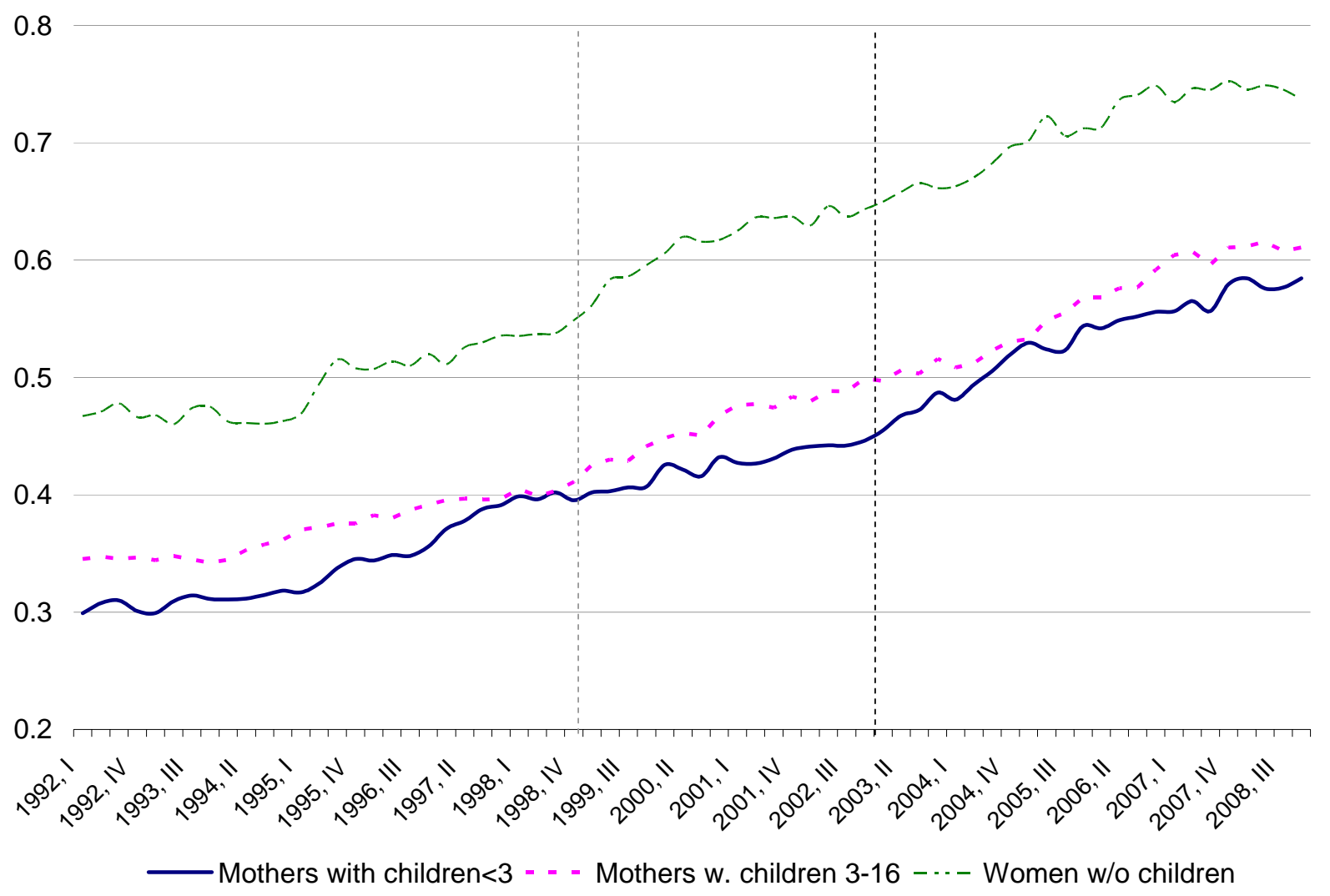

Source: Spanish Labor Force Survey (EPA), 1992-2008 (quarterly).

Note: The sample includes all women aged 18 to 45 with a partner. 
Figure 3. Participation rates, 1992-2008

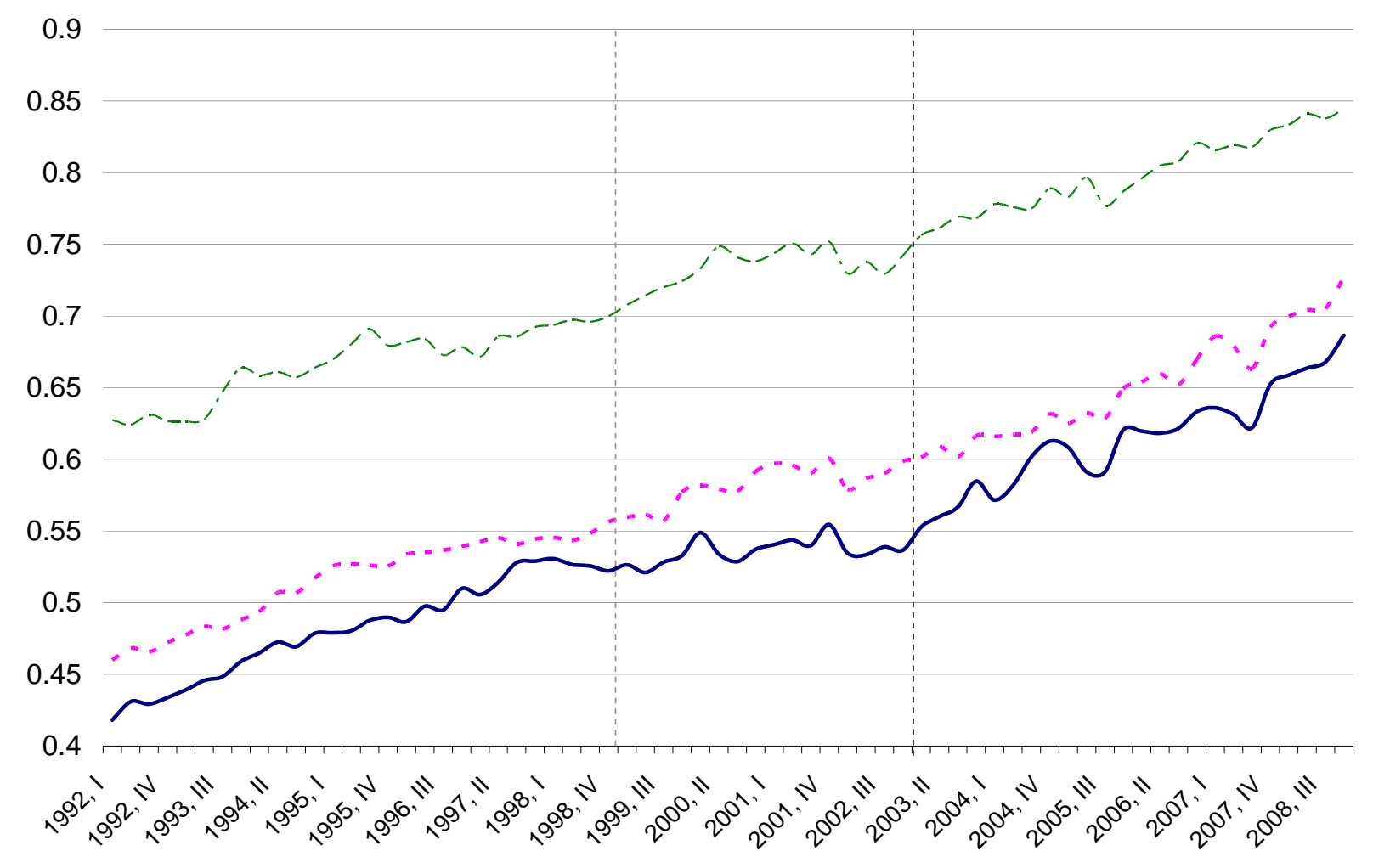

- Mothers w. children<3 - - - Mothers w. children 3-16 - - - Women w/o children

Source: Spanish Labor Force Survey (EPA), 1992-2008 (quarterly).

Note: The sample includes all women aged 18 to 45 with a partner. 
Table 1. Female participation rates and fertility rates in 13 OECD countries

\begin{tabular}{|lccc|cc|}
\hline & \multicolumn{3}{c|}{ Female employment rate } & \multicolumn{2}{c|}{ Total fertility rate } \\
\hline Countries & 1987 & 1997 & 2002 & 1997 & 2002 \\
\hline Belgium & 37.5 & 46.7 & 51.1 & 1.6 & 1.62 \\
Canada & 59.4 & 62.1 & 67 & 1.6 & 1.52 \\
France & 48.8 & 51.7 & 55.8 & 1.7 & 1.89 \\
Germany & 49.1 & 55.3 & 58.8 & 1.35 & 1.31 \\
Ireland & 34.1 & 44.7 & 55.2 & 1.91 & 1.97 \\
Italy & 34.5 & 36.4 & 42 & 1.17 & 1.26 \\
Netherlands & 42.3 & 57.6 & 64 & 1.54 & 1.73 \\
Norway & 70.7 & 72.2 & 73.9 & 1.86 & 1.75 \\
Portugal & 51.2 & 57.2 & 60.8 & 1.46 & 1.47 \\
Spain & 28.1 & 35.2 & 44.9 & 1.17 & 1.25 \\
Sweden & 79.2 & 68.9 & 73.4 & 1.51 & 1.65 \\
United Kingdom & 57.7 & 64 & 66.3 & 1.73 & 1.64 \\
United States & 61.9 & 67.1 & 66.1 & 2.03 & 2.01 \\
\hline
\end{tabular}

Sources: OECD Labour Force Statistics and OECD Social Indicators. 
Table 2. Subsidy by number of children and marginal tax rate

i) Subsidy for the birth of a new child (annual)

\begin{tabular}{|c|c|c|c|c|c|c|c|c|c|c|c|c|}
\hline \multicolumn{5}{|c|}{ Low bracket } & \multicolumn{4}{|c|}{ Middle bracket } & \multicolumn{4}{|c|}{ High bracket } \\
\hline $\begin{array}{l}\text { Parity of the newborn } \\
\text { child }\end{array}$ & 1 & 2 & 3 & 4 & 1 & 2 & 3 & 4 & 1 & 2 & 3 & 4 \\
\hline 1998 & 150 & 210 & 300 & 300 & 150 & 210 & 300 & 300 & 150 & 210 & 300 & 300 \\
\hline Post 1998 & 270 & 270 & 378 & 378 & 420 & 420 & 588 & 588 & 720 & 720 & 1008 & 1008 \\
\hline $\begin{array}{c}\text { Post } 2002 \\
\text { (plus } 1200 \text { if mother } \mathrm{w}\end{array}$ & $\begin{array}{l}390 \\
\text { (ing) }\end{array}$ & 405 & 510 & 525 & 728 & 756 & 952 & 980 & 1170 & 1215 & 1530 & 1575 \\
\hline Difference 1999-98 & 120 & 60 & 78 & 78 & 270 & 210 & 288 & 288 & 570 & 510 & 708 & 708 \\
\hline $\begin{array}{l}\text { Difference } 2003-02 \\
\text { (plus } 1200 \text { if mother w }\end{array}$ & $\begin{array}{r}120 \\
\text { (ing) } \\
\end{array}$ & 135 & 132 & 147 & 308 & 336 & 364 & 392 & 450 & 495 & 522 & 567 \\
\hline
\end{tabular}

Source: Spanish income tax legislation and own calculations.

Note: The numbers in the table indicate the annual tax savings (in euros) associated with the birth of a new child, depending on the number of other children present and the household's marginal tax rate. The low tax bracket is 18 percent for the 1999-2002 period and 15 percent for 2003-2008; the middle bracket is 28 percent, and the high brackets are 48 and 45 percent, respectively. 
ii) Total household subsidy by employment status of the mother

\begin{tabular}{|c|c|c|c|c|c|c|c|c|c|c|c|c|}
\hline NOT WORKING & \multicolumn{4}{|c|}{ Low bracket } & \multicolumn{4}{|c|}{ Middle bracket } & \multicolumn{4}{|c|}{ High bracket } \\
\hline N. of children & 1 & 2 & 3 & 4 & 1 & 2 & 3 & 4 & 1 & 2 & 3 & 4 \\
\hline 1998 & 150 & 360 & 660 & 960 & 150 & 360 & 660 & 960 & 150 & 360 & 660 & 960 \\
\hline Post 1998 & 270 & 514 & 865 & 1217 & 425 & 808 & 1360 & 1913 & 721 & 1370 & 2307 & 3245 \\
\hline Post 2002 & 390 & 615 & 945 & 1290 & 728 & 1148 & 1764 & 2408 & 1170 & 1845 & 2835 & 3870 \\
\hline difference 1999-98 & 120 & 154 & 205 & 257 & 275 & 448 & 700 & 953 & 571 & 1010 & 1647 & 2285 \\
\hline difference 2003-02 & 120 & 101 & 80 & 73 & 303 & 340 & 404 & 495 & 449 & 475 & 528 & 625 \\
\hline WORKING & \multicolumn{4}{|c|}{ Low bracket } & \multicolumn{4}{|c|}{ Middle bracket } & \multicolumn{4}{|c|}{ High bracket } \\
\hline N. of children & 1 & 2 & 3 & 4 & 1 & 2 & 3 & 4 & 1 & 2 & 3 & 4 \\
\hline 1998 & 150 & 360 & 660 & 960 & 150 & 360 & 660 & 960 & 150 & 360 & 660 & 960 \\
\hline Post 1998 & 270 & 514 & 865 & 1217 & 425 & 808 & 1360 & 1913 & 721 & 1370 & 2307 & 3245 \\
\hline Post 2002 & 1590 & 1815 & 2145 & 2490 & 1928 & 2348 & 2964 & 3608 & 2370 & 3045 & 4035 & 5070 \\
\hline difference 1999-98 & 120 & 154 & 205 & 257 & 275 & 448 & 700 & 953 & 571 & 1010 & 1647 & 2285 \\
\hline difference 2003-02 & 1320 & 1301 & 1280 & 1273 & 1503 & 1540 & 1604 & 1695 & 1649 & 1675 & 1728 & 1825 \\
\hline
\end{tabular}

Source: Spanish income tax legislation and own calculations.

Note: The numbers in the table indicate the annual tax savings generated by the child deductions, depending on the number of children and the household's marginal tax rate. We assume that each household has one child under three and, if multiple children, all others are under 16. The low tax bracket is 18 percent for the 1999-2002 period and 15 percent for 2003-2008; the middle bracket is 28 percent, and the high brackets are 48 and 45 percent, respectively. 
Table 3. Summary Statistics

\begin{tabular}{|c|c|c|c|c|c|c|c|c|}
\hline & \multicolumn{2}{|c|}{ Full sample } & \multicolumn{2}{|c|}{$\begin{array}{l}\text { Mothers w. } \\
\text { children<3 }\end{array}$} & \multicolumn{2}{|c|}{$\begin{array}{c}\text { Mothers w. } \\
\text { children 3-16 }\end{array}$} & \multicolumn{2}{|c|}{$\begin{array}{c}\text { Women without } \\
\text { children }\end{array}$} \\
\hline Variable & Mean & Std. Dev. & Mean & Std. Dev. & Mean & Std. Dev. & Mean & $\begin{array}{l}\text { Std. } \\
\text { Dev. }\end{array}$ \\
\hline Birth & 0.066 & 0.249 & 0.328 & 0.469 & 0 & 0 & 0 & 0 \\
\hline Employment & 0.475 & 0.499 & 0.423 & 0.494 & 0.448 & 0.497 & 0.611 & 0.488 \\
\hline Participation & 0.596 & 0.491 & 0.538 & 0.499 & 0.570 & 0.495 & 0.736 & 0.441 \\
\hline Children $<3$ & 0.202 & 0.401 & 1 & 0 & 0 & 0 & 0 & 0 \\
\hline Children $<17$ & 0.804 & 0.397 & 1 & 0 & 1 & 0 & 0 & 0 \\
\hline N. of children $<17$ & 1.377 & 0.955 & 1.729 & 0.816 & 1.708 & 0.722 & 0 & 0 \\
\hline N. children 1-2 & 0.147 & 0.366 & 0.727 & 0.493 & 0 & 0 & 0 & 0 \\
\hline N. children 3-5 & 0.231 & 0.452 & 0.244 & 0.449 & 0.302 & 0.499 & 0 & 0 \\
\hline N. children 6-12 & 0.563 & 0.710 & 0.342 & 0.584 & 0.820 & 0.733 & 0 & 0 \\
\hline N. children 13-16 & 0.369 & 0.617 & 0.082 & 0.336 & 0.586 & 0.689 & 0 & 0 \\
\hline Age & 35.804 & 6.089 & 31.804 & 4.904 & 37.757 & 4.993 & 33.922 & 7.487 \\
\hline Dropout & 0.273 & 0.445 & 0.176 & 0.380 & 0.328 & 0.469 & 0.203 & 0.402 \\
\hline High school grad & 0.567 & 0.495 & 0.614 & 0.487 & 0.547 & 0.498 & 0.581 & 0.493 \\
\hline University grad & 0.160 & 0.367 & 0.210 & 0.407 & 0.125 & 0.331 & 0.216 & 0.411 \\
\hline Immigrant & 0.057 & 0.232 & 0.070 & 0.256 & 0.044 & 0.205 & 0.083 & 0.275 \\
\hline N. observations & 1321523 & & 266629 & & 795777 & & 259117 & \\
\hline
\end{tabular}

Source: Spanish Labor Force Survey (EPA), 1992-2008 (quarterly).

Note: The sample includes all married or cohabiting women aged 18 to 45 . 
Table 4. Main Fertility Results

\begin{tabular}{|c|c|c|c|c|c|c|c|c|c|}
\hline \multirow{2}{*}{ No trend } & \multirow{2}{*}{$\frac{\text { Average fertility }}{0.0661}$} & \multicolumn{2}{|c|}{1999 reform } & & \multirow[t]{2}{*}{$\%$ effect } & \multicolumn{2}{|c|}{2003 reform } & \multirow[b]{2}{*}{$* * *$} & \multirow{2}{*}{$\frac{\text { \% effect }}{11.4 \%}$} \\
\hline & & & & & \multicolumn{2}{|c|}{$00075 \quad(0.0008)$} & & \\
\hline Linear trend & 0.0661 & & & & & 0.0081 & $(0.0008)$ & $* * *$ & $12.2 \%$ \\
\hline Linear and squared trend & 0.0661 & & & & & 0.0030 & $(0.0011)$ & $* * *$ & $4.6 \%$ \\
\hline Linear and squared trend (1992-2002) & 0.0638 & 0.0029 & $(0.0015)$ & $* *$ & $4.5 \%$ & & & & \\
\hline Linear and squared trend & 0.0661 & 0.0021 & $(0.0014)$ & & $3.2 \%$ & 0.0036 & $(0.0011)$ & $* * *$ & $5.5 \%$ \\
\hline
\end{tabular}

Note: The number of observations is 1,321,523. Each row corresponds to a different regression, and reports the coefficients on the "post 2002" and "post 1998" dummies. The dependent variable is always the proportion of women giving birth during the past 12 months. The sample includes all women aged 18-45 with a partner between 1992 and 2008 (unless otherwise noted). One asterisk indicates significance at the ten-percent level, two indicate five percent and three, one percent. The control variables include age, age squared, age cubed, education dummies, interactions between age and education, number of children in different age brackets, an immigrant dummy, quarter dummies, the quarterly unemployment rate, hourly wage and average house price, a linear and a square quarterly trend. The coefficients on the control variables are reported in Table A2. 
Table 5. Fertility Regression Results by Demographics

\begin{tabular}{|c|c|c|c|c|c|c|c|c|c|}
\hline By education & Average fertility & \multicolumn{3}{|c|}{1999 reform } & $\begin{array}{c}\% \\
\text { effect }\end{array}$ & \multicolumn{2}{|c|}{2003 reform } & & \multirow[t]{2}{*}{$\begin{array}{c}\% \\
\text { effect }\end{array}$} \\
\hline & & & & & & & & & \\
\hline High school dropouts & 0.0388 & 0.0048 & $(0.0020)$ & $* *$ & $12.5 \%$ & 0.0034 & $(0.0021)$ & $*$ & $8.8 \%$ \\
\hline High school graduates & 0.0719 & 0.0021 & $(0.0019)$ & & $2.9 \%$ & 0.0031 & $(0.0015)$ & $* *$ & $4.3 \%$ \\
\hline College graduates & 0.0923 & -0.0038 & $(0.0041)$ & & $-4.1 \%$ & 0.0052 & $(0.0032)$ & * & $5.7 \%$ \\
\hline \multicolumn{10}{|l|}{ By age } \\
\hline Younger than 31 & 0.1382 & 0.0117 & $(0.0042)$ & $* * *$ & $8.5 \%$ & 0.0091 & $(0.0037)$ & $* *$ & $6.6 \%$ \\
\hline Older than 30 & 0.0468 & 0.0001 & $(0.0013)$ & & $0.1 \%$ & 0.0025 & $(0.0011)$ & $* *$ & $5.3 \%$ \\
\hline \multicolumn{10}{|c|}{ By number of previous children } \\
\hline No previous children & 0.1304 & 0.0032 & $(0.0039)$ & & $2.5 \%$ & 0.0091 & $(0.0031)$ & $* * *$ & $7.0 \%$ \\
\hline One previous child & 0.0825 & 0.0025 & $(0.0025)$ & & $3.0 \%$ & 0.0009 & $(0.0021)$ & & $1.1 \%$ \\
\hline Two plus previous children & 0.0197 & 0.0024 & $(0.0012)$ & $* *$ & $12.0 \%$ & 0.0015 & $(0.0010)$ & & $7.6 \%$ \\
\hline
\end{tabular}

Note: Each row corresponds to a different regression, and reports the coefficients on the "post 2002" and "post 1998" dummies. The dependent variable is always the proportion of women giving birth during the past 12 months. The sample includes all women aged 18-45 with a partner between 1992 and 2008. One asterisk indicates significance at the ten-percent level, two indicate five percent and three, one percent. The control variables include age, age squared, age cubed, education dummies, interactions between age and education, number of children in different age brackets, an immigrant dummy, quarter dummies, the quarterly unemployment rate, hourly wage and average house price, a linear and a square quarterly trend. 
Table 6. Main Employment and Participation Results

\begin{tabular}{|c|c|c|c|c|c|c|c|c|}
\hline \multirow{3}{*}{\begin{tabular}{|l|} 
\\
Treat*Post2002
\end{tabular}} & \multicolumn{4}{|c|}{ All Married Women } & \multirow{2}{*}{\multicolumn{2}{|c|}{$\begin{array}{l}\text { Married Mothers } \\
\text { Employment }\end{array}$}} & \multirow{2}{*}{\multicolumn{2}{|c|}{ Participation }} \\
\hline & \multicolumn{2}{|c|}{ Employment } & \multicolumn{2}{|c|}{ Participation } & & & & \\
\hline & $\begin{array}{r}0.0088 \\
(0.0038)\end{array}$ & ** & $\begin{array}{r}0.0129 \\
(0.0038)\end{array}$ & $* * *$ & \multicolumn{2}{|l|}{$\begin{array}{r}0.0026 \\
(0.0040)\end{array}$} & $\begin{array}{r} \\
0.0091 \\
(0.0040)\end{array}$ & $* *$ \\
\hline Treat & $\begin{array}{r}-0.0178 \\
(0.0100)\end{array}$ & $*$ & $\begin{array}{r}-0.0323 \\
(0.0099)\end{array}$ & $* * *$ & $\begin{array}{r}-0.0123 \\
(0.0102)\end{array}$ & & $\begin{array}{r}-0.0107 \\
(0.0104)\end{array}$ & \\
\hline Post 2002 & $\begin{array}{r}0.0271 \\
(0.0017)\end{array}$ & $* * *$ & $\begin{array}{r}0.0055 \\
(0.0017)\end{array}$ & $* * *$ & $\begin{array}{r}0.0336 \\
(0.0020)\end{array}$ & $* * *$ & $\begin{array}{r}0.0093 \\
(0.0020)\end{array}$ & $* * *$ \\
\hline Trend & $\begin{array}{r}0.0024 \\
(0.0000)\end{array}$ & $* * *$ & $\begin{array}{r}0.0018 \\
(0.0000)\end{array}$ & $* * *$ & $\begin{array}{r}0.002 \\
(0.0000)\end{array}$ & $* * *$ & $\begin{array}{r}0.0016 \\
(0.0000)\end{array}$ & $* * *$ \\
\hline Trend*Treat & $\begin{array}{r}-0.0003 \\
(0.0001)\end{array}$ & $* * *$ & $\begin{array}{r}-0.0002 \\
(0.0001)\end{array}$ & $* *$ & $\begin{array}{r}-0.0001 \\
(0.0001)\end{array}$ & & $\begin{array}{r}-0.0002 \\
(0.0001)\end{array}$ & $* *$ \\
\hline $\mathrm{N}$ & 1321523 & & 1321523 & & 1062406 & & 1062406 & \\
\hline
\end{tabular}

Note: Each column reports the results from a different regression. The dependent variable is an indicator for current employment or labor-force participation, as indicated in the column header. "Treat" is an indicator for children under the age of three. Columns (1) and (2) include all married women, while columns (3) and (4) include only mothers of children aged zero to 16 years, always in the age range 18-45 and between 1992 and 2008. One asterisk indicates significance at the tenpercent level, two indicate five percent and three, one percent. Additional control variables included in all specifications are quarter dummies, age, age squared, dummies for number of children in different age ranges, educational attainment dummies and an immigrant status indicator. The coefficients of the controls are reported in Table A3. 
Table 7. Employment and Participation Regression Results by Demographics

\begin{tabular}{|c|c|c|c|c|c|c|c|c|c|c|}
\hline & $\begin{array}{l}\text { Average emp. } \\
\text { rate }\end{array}$ & Em & ployment & & $\begin{array}{c}\% \\
\text { effect }\end{array}$ & $\begin{array}{l}\text { Average part. } \\
\text { rate }\end{array}$ & Partici & pation & & $\begin{array}{c}\% \\
\text { effect }\end{array}$ \\
\hline Basic Specification & 0.4748 & 0.0088 & $(0.0038)$ & $* *$ & $1.9 \%$ & 0.5962 & 0.0129 & $(0.0038)$ & $* * *$ & $2.2 \%$ \\
\hline \multicolumn{11}{|l|}{ By education } \\
\hline $\begin{array}{l}\text { High school } \\
\text { dropouts }\end{array}$ & 0.2982 & 0.0219 & $(0.0096)$ & $* *$ & $7.3 \%$ & 0.4244 & 0.0087 & $(0.0103)$ & & $2.0 \%$ \\
\hline $\begin{array}{l}\text { High school } \\
\text { graduates }\end{array}$ & 0.4719 & 0.0088 & $(0.0051)$ & $*$ & $1.9 \%$ & 0.6034 & 0.0088 & $(0.0050)$ & $*$ & $1.5 \%$ \\
\hline College graduates & 0.7855 & 0.0058 & $(0.0075)$ & & $0.7 \%$ & 0.8629 & 0.0097 & $(0.0063)$ & & $1.1 \%$ \\
\hline \multicolumn{11}{|l|}{ By age } \\
\hline Younger than 31 & 0.4564 & 0.0221 & $(0.0070)$ & $* * *$ & $4.8 \%$ & 0.6254 & 0.0316 & $(0.0069)$ & $* * *$ & $5.1 \%$ \\
\hline Older than 30 & 0.6254 & 0.0115 & $(0.0047)$ & $* *$ & $1.8 \%$ & 0.5884 & 0.0146 & $(0.0090)$ & $* * *$ & $2.5 \%$ \\
\hline \multicolumn{11}{|c|}{ By number of children } \\
\hline One & 0.4805 & -0.0028 & $(0.0060)$ & & $-0.6 \%$ & 0.6062 & -0.0015 & $(0.0060)$ & & $-0.2 \%$ \\
\hline Two & 0.4323 & 0.0077 & $(0.0060)$ & & $1.8 \%$ & 0.5495 & 0.0187 & $(0.0061)$ & $* * *$ & $3.4 \%$ \\
\hline Three & 0.3500 & 0.0063 & $(0.0126)$ & & $1.8 \%$ & 0.4634 & 0.0222 & $(0.0134)$ & $*$ & $4.8 \%$ \\
\hline Four or more & 0.2602 & 0.0093 & $(0.0302)$ & & $3.6 \%$ & 0.3755 & 0.0045 & $(0.0337)$ & & $1.2 \%$ \\
\hline
\end{tabular}

Note: Each row reports the results from a different regression. The dependent variable is an indicator for employment (column 1) and an indicator for labor force participation (column 2). The sample includes all married women aged 18-45 between 1992 and 2008 . The coefficients reported correspond to an indicator variable for post-2002 interacted with children under three. Controls included are a separate dummies for post-2002 and children under three, a linear trend, a linear trend interacted with children under three, quarter dummies, age, age squared, dummies for number of children in different age ranges, educational attainment dummies and an immigrant status indicator.. One asterisk indicates significance at the ten-percent level, two indicate five percent and three, one percent. 
Table 8. Two-Stage Employment and Participation Regressions

Panel A. First-Stage Results (Employment and Participation Effects, 1999 Reform)

\begin{tabular}{|c|c|c|c|c|c|c|c|c|}
\hline & Employment & & Employment & & Participation & & Participation & \\
\hline (Post 1998*Mother) & $\begin{array}{r}-0.0132 \\
(0.0048)\end{array}$ & $* * *$ & & & $\begin{array}{r}-0.0117 \\
(0.0048)\end{array}$ & $* *$ & & \\
\hline Post 1998 & $\begin{array}{r}0.0394 \\
(0.0043)\end{array}$ & $* * *$ & $\begin{array}{r}0.0364 \\
(0.0040)\end{array}$ & $* * *$ & $\begin{array}{r}0.0094 \\
(0.0044)\end{array}$ & $* *$ & $\begin{array}{r}0.0076 \\
(0.0040)\end{array}$ & $*$ \\
\hline Mother (children<17) & $\begin{array}{r}0.088 \\
(0.0172)\end{array}$ & $* * *$ & & & $\begin{array}{r}-0.0058 \\
(0.0174)\end{array}$ & & & \\
\hline$\left(\right.$ Post $\left.1998 * \Delta \operatorname{tax} 1 * \mathrm{D}_{1 \mathrm{kid}}\right)$ & & & $\begin{array}{r}-0.0059 \\
(0.0175)\end{array}$ & & & & $\begin{array}{r}-0.034 \\
(0.0177)\end{array}$ & $*$ \\
\hline$\left(\right.$ Post $\left.1998 * \Delta \operatorname{tax} 2 * \mathrm{D}_{2 \mathrm{kid}}\right)$ & & & $\begin{array}{r}-0.038 \\
(0.0117)\end{array}$ & $* * *$ & & & $\begin{array}{r}-0.029 \\
(0.0119)\end{array}$ & $* *$ \\
\hline$\left(\right.$ Post $\left.1998 * \Delta \operatorname{tax} 3 * \mathrm{D}_{3 \mathrm{kid}}\right)$ & & & $\begin{array}{r}-0.039 \\
(0.0096)\end{array}$ & $* * *$ & & & $\begin{array}{r}-0.014 \\
(0.0097)\end{array}$ & \\
\hline$\left(\right.$ Post $\left.1998 * \Delta \operatorname{tax} 4 * \mathrm{D}_{4 \mathrm{kid}}\right)$ & & & $\begin{array}{r}-0.039 \\
(0.0122)\end{array}$ & $* * *$ & & & $\begin{array}{r}-0.013 \\
(0.0123)\end{array}$ & \\
\hline One child $\left(\mathrm{D}_{1 \mathrm{kid}}\right)$ & & & $\begin{array}{r}0.0573 \\
(0.0162)\end{array}$ & $* * *$ & & & $\begin{array}{c}-0.0401 \\
(0.0164)\end{array}$ & $* *$ \\
\hline Two children $\left(\mathrm{D}_{2 \mathrm{kid}}\right)$ & & & $\begin{array}{r}0.0166 \\
(0.0163)\end{array}$ & & & & $\begin{array}{r}-0.0892 \\
(0.0165)\end{array}$ & $* * *$ \\
\hline Three children $\left(\mathrm{D}_{3 \mathrm{kid}}\right)$ & & & $\begin{array}{r}-0.0237 \\
(0.0164)\end{array}$ & & & & $\begin{array}{r}-0.1381 \\
(0.0166)\end{array}$ & $* * *$ \\
\hline Four or more children (D4 $\left.4_{\mathrm{kid}}\right)$ & & & $\begin{array}{r}-0.0623 \\
(0.0169)\end{array}$ & $* * *$ & & & $\begin{array}{r}-0.1734 \\
(0.0171)\end{array}$ & $* * *$ \\
\hline Trend & $\begin{array}{r}0.0022 \\
(0.0002)\end{array}$ & $* * *$ & $\begin{array}{r}0.0023 \\
(0.0002)\end{array}$ & $* * *$ & $\begin{array}{r}0.0016 \\
(0.0002)\end{array}$ & $* * *$ & $\begin{array}{r}0.0016 \\
(0.0002)\end{array}$ & $* * *$ \\
\hline Trend*Mother & $\begin{array}{r}-0.0013 \\
(0.0002)\end{array}$ & $* * *$ & $\begin{array}{r}-0.0014 \\
(0.0002)\end{array}$ & $* * *$ & $\begin{array}{r}-0.0002 \\
(0.0002)\end{array}$ & & $\begin{array}{r}-0.0003 \\
(0.0002)\end{array}$ & \\
\hline $\mathrm{N}$ & 897737 & & 897737 & & 897737 & & 897737 & \\
\hline
\end{tabular}

Note: The dependent variable is an indicator for employment or labor-force participation, as indicated in the column header. We also include controls for age, age squared, the ages of the children, education level and quarter. $\mathrm{D}_{\mathrm{i} k i d}$ is a dummy variable indicating the number of children. The sample includes all married women aged 18-45 between 1992 and 2000. The $\Delta \operatorname{tax} 1-\Delta \operatorname{tax} 4$ amounts are given in Table 2 and included in this regression in units of 1000 euros. The table reports the results from using the middle tax bracket (28 percent). One asterisk indicates significance at the ten-percent level, two indicate five percent and three, one percent. 
Panel B. Second-Stage Results (Adjusted Employment and Participation Effects, 2003 Reform)

\begin{tabular}{|c|c|c|c|c|c|c|c|c|c|c|c|c|}
\hline & \multirow{2}{*}{\multicolumn{2}{|c|}{$\begin{array}{c}\text { Employment } \\
\text { Two-stage } \\
\text { results } \\
\end{array}$}} & \multicolumn{10}{|c|}{ Participation } \\
\hline & & & \multicolumn{2}{|c|}{$\begin{array}{c}\text { Original (1992- } \\
2008 \text { sample) } \\
\end{array}$} & \multicolumn{2}{|c|}{$\begin{array}{c}2000-2008 \\
\text { sample }\end{array}$} & \multicolumn{2}{|c|}{$\begin{array}{c}\text { Two-stage } \\
\text { results }\end{array}$} & \multicolumn{2}{|c|}{$\begin{array}{c}\text { Original (1992- } \\
2008 \text { sample) } \\
\end{array}$} & \multicolumn{2}{|c|}{$\begin{array}{c}2000-2008 \\
\text { sample }\end{array}$} \\
\hline Treat*Post 2002 & $\begin{array}{r}0.0234 \\
(0.0053)\end{array}$ & $* * *$ & $\begin{array}{r}0.0088 \\
(0.0038)\end{array}$ & $* *$ & $\begin{array}{r}0.0168 \\
(0.0053)\end{array}$ & $* * *$ & $\begin{array}{l}0.0206 \\
0.0051\end{array}$ & $* * *$ & $\begin{array}{r}0.0129 \\
(0.0038)\end{array}$ & $* * *$ & $\begin{array}{r}0.0128 \\
(0.0051)\end{array}$ & $* * *$ \\
\hline Treat & $\begin{array}{r}-0.0501 \\
(0.0282)\end{array}$ & $*$ & $\begin{array}{r}-0.0178 \\
(0.0100)\end{array}$ & $*$ & $\begin{array}{r}-0.0458 \\
(0.0208)\end{array}$ & & $\begin{array}{r}-0.0786 \\
0.0271\end{array}$ & $* * *$ & $\begin{array}{r}-0.0323 \\
(0.0099)\end{array}$ & $* * *$ & $\begin{array}{r}-0.0787 \\
(0.0271)\end{array}$ & $* * *$ \\
\hline Post 2002 & $\begin{array}{r}-0.0124 \\
(0.0024)\end{array}$ & $* * *$ & $\begin{array}{r}0.0271 \\
(0.0017)\end{array}$ & $* * *$ & $\begin{array}{r}-0.014 \\
(0.0024)\end{array}$ & $* * *$ & $\begin{array}{r}-0.0168 \\
0.0023\end{array}$ & $* * *$ & $\begin{array}{r}0.0055 \\
(0.0017)\end{array}$ & $* * *$ & $\begin{array}{r}-0.018 \\
(0.0023)\end{array}$ & $* * *$ \\
\hline Trend & $\begin{array}{r}0.0043 \\
(0.0001)\end{array}$ & $* * *$ & $\begin{array}{r}0.0024 \\
(0.0000)\end{array}$ & $* * *$ & $\begin{array}{r}0.0043 \\
(0.0001)\end{array}$ & $* * *$ & $\begin{array}{r}0.0032 \\
(0.0001)\end{array}$ & $* * *$ & $\begin{array}{r}0.0018 \\
(0.0000)\end{array}$ & $* * *$ & $\begin{array}{r}0.0032 \\
(0.0001)\end{array}$ & $* * *$ \\
\hline Trend*Treat & $\begin{array}{r}-0.0002 \\
(0.0002)\end{array}$ & & $\begin{array}{r}-0.0003 \\
(0.0001)\end{array}$ & $* * *$ & $\begin{array}{r}-0.0002 \\
(0.0002)\end{array}$ & & $\begin{array}{r}0.0002 \\
(0.0002)\end{array}$ & & $\begin{array}{r}-0.0002 \\
(0.0001)\end{array}$ & $* *$ & $\begin{array}{r}0.0002 \\
(0.0002)\end{array}$ & \\
\hline $\mathrm{N}$ & 649009 & & 1321523 & & 649009 & & 649009 & & 1321523 & & 649009 & \\
\hline
\end{tabular}

Note: The dependent variable is an indicator for employment (first panel) or labor-force participation (second panel). Column 1 in each panel shows the second stage of the two-stage estimation, controlling for the employment effect resulting from the estimated coefficients from the 1999 tax reform. The sample includes all married women aged 18-45 between 2000 and 2008 (except the second column of each panel, which include, 1992-2008). Additional control variables included in all specifications are quarter dummies, age, age squared, dummies for number of children in different age ranges, educational attainment dummies and an immigrant status 
Table A1. Child Deductions and Tax Credits (in euros), Spain 1991-2008

\begin{tabular}{|c|c|c|c|c|c|c|c|c|}
\hline & $\begin{array}{c}1 \text { st } \\
\text { child }\end{array}$ & 2nd & 3rd & 4 th + & $\begin{array}{l}\text { Deduction } \\
\text { or tax } \\
\text { credit? }\end{array}$ & $\begin{array}{l}\text { Supplements } \\
\text { age } 0-2\end{array}$ & $\begin{array}{l}\text { Supplements } \\
\text { age 3-16 }\end{array}$ & $\begin{array}{l}\text { Tax Credit } \\
\text { (conditional on } \\
\text { mothers' } \\
\text { employment) }\end{array}$ \\
\hline 1991 & 120 & 120 & 120 & 120 & tax credit & & & \\
\hline 1992 & 120 & 120 & 120 & 120 & tax credit & & & \\
\hline 1993 & 120 & 120 & 120 & 120 & tax credit & & & \\
\hline 1994 & 120 & 120 & 120 & 120 & tax credit & & & \\
\hline 1995 & 124 & 124 & 150 & 180 & tax credit & & & \\
\hline 1996 & 129 & 129 & 156 & 186 & tax credit & & & \\
\hline 1997 & 133 & 133 & 160 & 191 & tax credit & & & \\
\hline 1998 & 150 & 210 & 300.5 & 300.5 & tax credit & & & \\
\hline 1999 & 1202 & 1202 & 1803 & 1803 & deduction & 300.5 & 150 & \\
\hline 2000 & 1202 & 1202 & 1803 & 1803 & deduction & 300.5 & 150 & \\
\hline 2001 & 1202 & 1202 & 1803 & 1803 & deduction & 300.5 & 150 & \\
\hline 2002 & 1202 & 1202 & 1803 & 1803 & deduction & 300.5 & 150 & \\
\hline 2003 & 1400 & 1500 & 2200 & 2300 & deduction & 1200 & & 1200 \\
\hline 2004 & 1400 & 1500 & 2200 & 2300 & deduction & 1200 & & 1200 \\
\hline 2005 & 1400 & 1500 & 2200 & 2300 & deduction & 1200 & & 1200 \\
\hline 2006 & 1400 & 1500 & 2200 & 2300 & deduction & 1200 & & 1200 \\
\hline 2007 & 1800 & 2000 & 3600 & 4100 & deduction & 1200 & & 1200 \\
\hline 2008 & 1800 & 2000 & 3600 & 4100 & deduction & 1200 & & 1200 \\
\hline
\end{tabular}

Source: Spanish Income-Tax Legislation.

Note: A tax credit is an amount that you subtract from a household's tax liability (after applying the tax rate to taxable income). A deduction is an amount that you subtract from your taxable income, before you apply the tax rate. From 2003 on, the 1,200-euro tax credit was for families with children under the age of three, conditional on the mother's employment. 
Table A2. Fertility Regressions, Individual and Aggregate Controls

\begin{tabular}{|lrrl|}
\hline Variable & Coef. & Std. Err. & \\
Age & 0.0324 & $(0.0047)$ & $* * *$ \\
Age sq. & -0.0013 & $(0.0001)$ & $* * *$ \\
Age cubed & 0.0000 & $(0.0000)$ & $* * *$ \\
High school grad & -0.7064 & $(0.0605)$ & $* * *$ \\
Univ grad & -4.5185 & $(0.1289)$ & $* * *$ \\
Age*High school & 0.0518 & $(0.0056)$ & $* * *$ \\
Age2*High school & -0.0012 & $(0.0002)$ & $* * *$ \\
Age3*High school & 0.0000 & $(0.0000)$ & $* * *$ \\
Age*Univ & 0.3532 & $(0.0114)$ & $* * *$ \\
Age2*Univ & -0.0089 & $(0.0003)$ & $* * *$ \\
Age3*Univ & 0.0000 & $(0.0000)$ & $* * *$ \\
Immigrant & -0.0003 & $(0.0009)$ & \\
N. kids 1-2 & -0.0786 & $(0.0006)$ & $* * *$ \\
N. kids3-5 & -0.0225 & $(0.0005)$ & $* * *$ \\
N. kids6-12 & -0.0346 & $(0.0003)$ & $* * *$ \\
N. kids 13-16 & -0.0249 & $(0.0004)$ & $* * *$ \\
& & & \\
N & 1321523 & & \\
\hline & & & \\
Unemp. Rate & -0.0004 & $(0.0001)$ & $* * *$ \\
Hourly wage & -0.0032 & $(0.0015)$ & $* *$ \\
House price & 0.0003 & $(0.0003)$ & \\
Linear trend & -0.0006 & $(0.0004)$ & $*$ \\
Squared trend & 0.0000 & $(0.0000)$ & $* * *$ \\
2nd quarter & 0.0020 & $(0.0011)$ & $*$ \\
3rd quarter & 0.0043 & $(0.0019)$ & $* *$ \\
4th quarter & 0.0050 & $(0.0023)$ & $* *$ \\
& & & \\
N & 68 & & \\
\hline
\end{tabular}

Note: The dependent variable is an indicator for having given birth during the past 12 months. The sample includes all partnered women aged 18-45 between 1992 and 2008. One asterisk indicates significance at the ten-percent level, two indicate five percent and three, one percent.

Source: The unemployment rate, the hourly wage and the house price are all average (annual) variables taken from the OECD Statistical Compendium. The other variables come from the Spanish Labor Force Survey (EPA). 
Table A3. Employment and Participation Regressions, Individual Controls

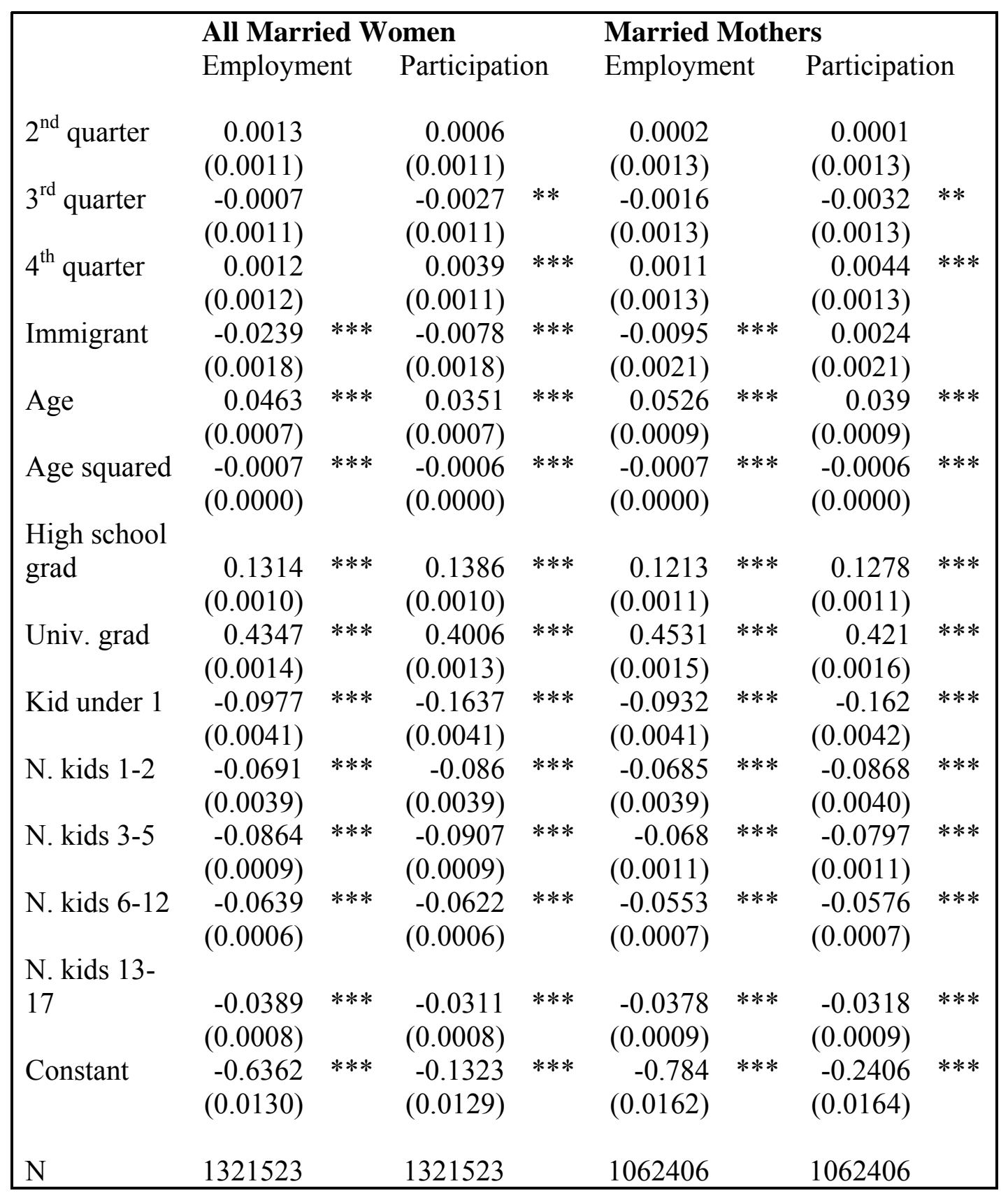

Note: The dependent variable is an indicator employment (or participation). The sample includes all partnered women aged 18-45 between 1992 and 2008. One asterisk indicates significance at the tenpercent level, two indicate five percent and three, one percent. 
Table A4. Second-Stage Results by Education and Tax Bracket

\begin{tabular}{|c|c|c|c|c|c|c|c|c|c|}
\hline \multirow{2}{*}{$\begin{array}{l}\text { Employment } \\
\text { Treat*Post2002 }\end{array}$} & \multicolumn{2}{|c|}{$\begin{array}{l}\text { Low tax } \\
\text { bracket }\end{array}$} & \multicolumn{2}{|c|}{$\begin{array}{c}\text { High tax } \\
\text { bracket }\end{array}$} & \multicolumn{2}{|c|}{$\begin{array}{c}\text { Dropouts, low } \\
\text { tax bracket }\end{array}$} & \multicolumn{2}{|c|}{$\begin{array}{l}\text { High school } \\
\text { grads, middle tax } \\
\text { bracket }\end{array}$} & \multirow{2}{*}{$\begin{array}{c}\text { Univ. grads, } \\
\text { high tax } \\
\text { bracket } \\
\\
0.0128 \\
(0.0092)\end{array}$} \\
\hline & $\begin{array}{r}0.0266 \\
(0.0053)\end{array}$ & $* * *$ & $\begin{array}{r}0.0212 \\
(0.0053)\end{array}$ & $* * *$ & $\begin{array}{r}0.05 \\
(0.0157)\end{array}$ & $* * *$ & $\begin{array}{r}0.0207 \\
(0.0069)\end{array}$ & $* * *$ & \\
\hline Treat & $\begin{array}{r}-0.0509 \\
(0.0282)\end{array}$ & $*$ & $\begin{array}{r}-0.0481 \\
(0.0282)\end{array}$ & $*$ & $\begin{array}{r}0.0521 \\
(0.0873)\end{array}$ & & $\begin{array}{r}-0.0721 \\
(0.0368)\end{array}$ & $*$ & $\begin{array}{r}0.0136 \\
(0.0469)\end{array}$ \\
\hline Post 2002 & $\begin{array}{r}-0.0154 \\
(0.0024)\end{array}$ & $* * *$ & $\begin{array}{r}-0.0134 \\
(0.0024)\end{array}$ & $* * *$ & $\begin{array}{r}-0.0292 \\
(0.0058)\end{array}$ & $* * *$ & $\begin{array}{r}-0.0107 \\
(0.0031)\end{array}$ & $* * *$ & $\begin{array}{r}0.0036 \\
(0.0047)\end{array}$ \\
\hline $\mathrm{N}$ & 649009 & & 649009 & & 101505 & & 418617 & & 128887 \\
\hline Participation & \multicolumn{2}{|c|}{$\begin{array}{l}\text { Low tax } \\
\text { bracket }\end{array}$} & \multicolumn{2}{|c|}{$\begin{array}{c}\text { High tax } \\
\text { bracket }\end{array}$} & \multicolumn{2}{|c|}{$\begin{array}{l}\text { Dropouts, low } \\
\text { tax bracket }\end{array}$} & \multicolumn{2}{|c|}{$\begin{array}{l}\text { High school } \\
\text { grads, middle tax } \\
\text { bracket }\end{array}$} & $\begin{array}{c}\text { Univ. grads, } \\
\text { high tax } \\
\text { bracket }\end{array}$ \\
\hline Treat*Post2002 & $\begin{array}{r}0.0246 \\
(0.0051)\end{array}$ & $* * *$ & $\begin{array}{r}0.0183 \\
(0.0051)\end{array}$ & $* * *$ & $\begin{array}{r}0.0547 \\
(0.0164)\end{array}$ & $* * *$ & $\begin{array}{r}0.0113 \\
(0.0066)\end{array}$ & $*$ & $\begin{array}{r}0.0067 \\
(0.0079)\end{array}$ \\
\hline Treat & $\begin{array}{r}-0.0797 \\
(0.0271)\end{array}$ & $* * *$ & $\begin{array}{c}-0.0782 \\
(0.0271)\end{array}$ & $* * *$ & $\begin{array}{r}0.1303 \\
(0.0913)\end{array}$ & & $\begin{array}{r}-0.1123 \\
(0.0354)\end{array}$ & $* * *$ & $\begin{array}{r}-0.0405 \\
(0.0404)\end{array}$ \\
\hline Post 2002 & $\begin{array}{r}-0.02 \\
(0.0023)\end{array}$ & $* * *$ & $\begin{array}{l}-0.0177 \\
(0.0023)\end{array}$ & $* * *$ & $\begin{array}{r}-0.0324 \\
(0.0061)\end{array}$ & $* * *$ & $\begin{array}{r}-0.0107 \\
(0.0031)\end{array}$ & $* * *$ & $\begin{array}{r}-0.0001 \\
(0.0040)\end{array}$ \\
\hline $\mathrm{N}$ & 649009 & & 649009 & & 101505 & & 418617 & & 128887 \\
\hline
\end{tabular}

Note: The dependent variable is an indicator for employment (first panel) or labor-force participation (second panel). Each column in each panel shows the results from a different regression, corresponding to the second stage of the two-stage estimation, which controls for the employment effect resulting from the estimated coefficients from the 1999 tax reform. The sample includes all married women aged 18-45 between 2000 and 2008. Additional control variables included in all specifications are a linear trend, a linear trend interacted with "treat," quarter dummies, age, age squared, dummies for number of children in different age ranges, educational attainment dummies and an immigrant status indicator. The low tax bracket was 18 percent in 1999 (15 percent in 2003), while the high tax bracket was 48 percent in 1999 (45 percent in 2003). One asterisk indicates significance at the ten-percent level, two indicate five percent and three, one percent. 
Table A5. Weekly Hours of Work Regression Results

\begin{tabular}{|c|c|c|c|c|c|c|c|c|}
\hline \multirow[b]{3}{*}{ Treat*Post 2002} & \multicolumn{4}{|c|}{ All Married Women } & \multicolumn{4}{|c|}{ Married Mothers } \\
\hline & \multicolumn{2}{|c|}{ Usual hours } & \multicolumn{2}{|c|}{ Actual hours } & \multicolumn{2}{|c|}{ Usual hours } & \multicolumn{2}{|c|}{ Actual hours } \\
\hline & $\begin{array}{r}-0.5511 \\
(0.1323)\end{array}$ & $* * *$ & $\begin{array}{r}-0.6580 \\
(0.1564)\end{array}$ & $* * *$ & $\begin{array}{r}-0.4392 \\
(0.1410)\end{array}$ & $* * *$ & $\begin{array}{r}-0.5360 \\
(0.1653)\end{array}$ & $* * *$ \\
\hline Treat & $\begin{array}{r}-0.4364 \\
(0.3669)\end{array}$ & & $\begin{array}{r}0.0602 \\
(0.4380)\end{array}$ & & $\begin{array}{r}-1.1202 \\
(0.3884)\end{array}$ & $* * *$ & $\begin{array}{r}-0.6845 \\
(0.0772)\end{array}$ & \\
\hline Post 2002 & $\begin{array}{r}0.1636 \\
(0.0555)\end{array}$ & $* * *$ & $\begin{array}{r}0.2349 \\
(0.0626)\end{array}$ & $* * *$ & $\begin{array}{r}0.0733 \\
(0.0688)\end{array}$ & & $\begin{array}{r}0.1386 \\
(0.4598)\end{array}$ & $*$ \\
\hline Trend & $\begin{array}{r}-0.0472 \\
(0.0014)\end{array}$ & $* * *$ & $\begin{array}{r}-0.0387 \\
(0.0016)\end{array}$ & $* * *$ & $\begin{array}{r}-0.0624 \\
(0.0017)\end{array}$ & $* * *$ & $\begin{array}{r}-0.0545 \\
(0.0019)\end{array}$ & $* * *$ \\
\hline Trend*Treat & $\begin{array}{r}-0.0055 \\
(0.0033)\end{array}$ & $*$ & $\begin{array}{r}-0.0118 \\
(0.0039)\end{array}$ & $* * *$ & $\begin{array}{r}0.0067 \\
(0.0035)\end{array}$ & $*$ & $\begin{array}{r}0.0009 \\
(0.0041)\end{array}$ & \\
\hline $\mathrm{N}$ & 622600 & & 560603 & & 465713 & & 417154 & \\
\hline
\end{tabular}

Note: Each column reports the results from a different regression. The dependent variable is the weekly number of hours worked conditional on employment (usual hours worked or actual hours worked the previous week, as indicated in the column header). "Treat" is an indicator for children under the age of three. Columns (1) and (2) include all married women, while columns (3) and (4) include only mothers of children aged zero to 16 years, always in the age range 18-45 and between 1992 and 2008. One asterisk indicates significance at the ten-percent level, two indicate five percent and three, one percent Additional control variables included in all specifications are quarter dummies, age, age squared, dummies for number of children in different age ranges, educational attainment dummies and an immigrant status indicator. 
Table A6. Propensity Score Matching Results

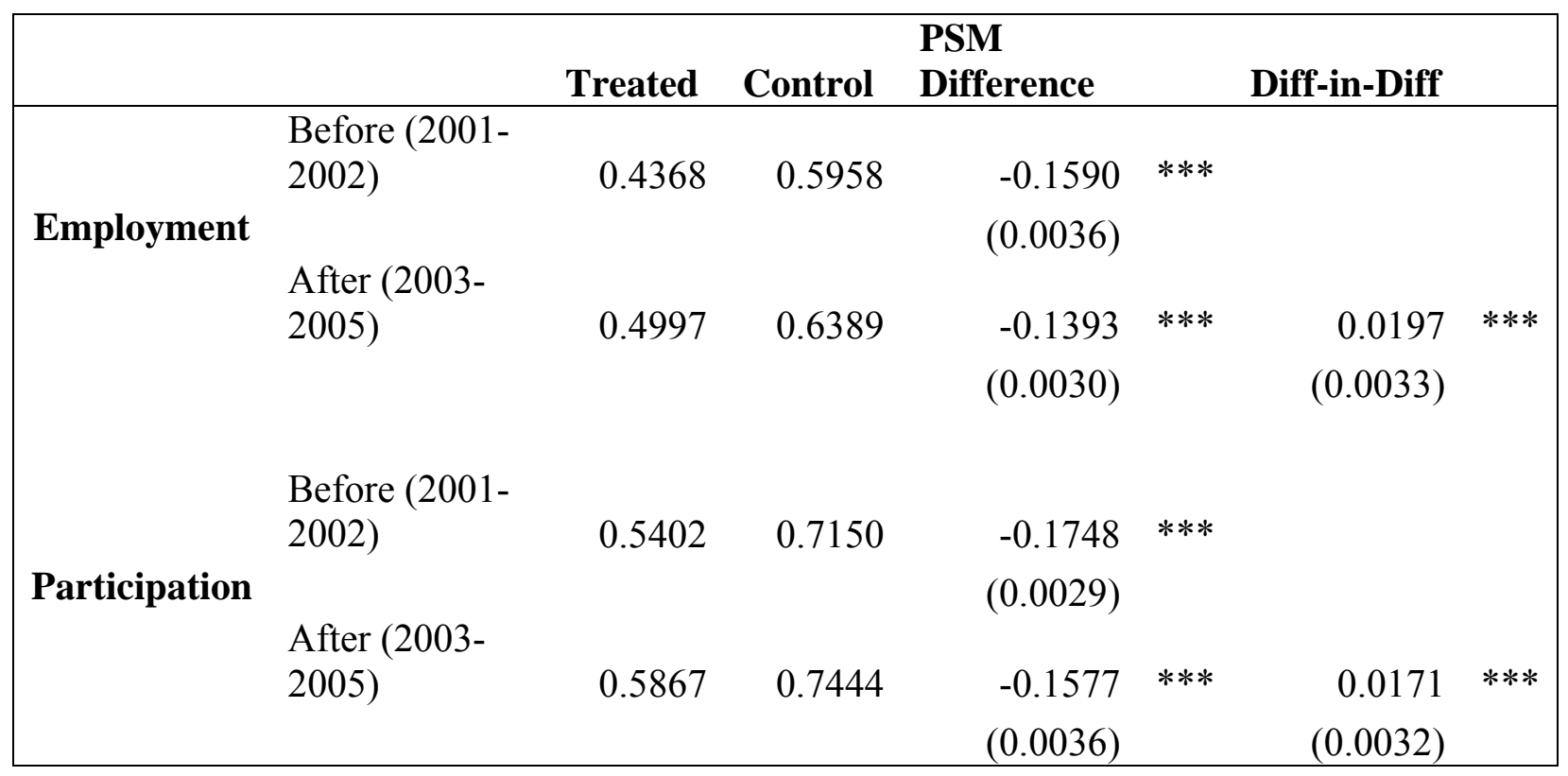

Note: The sample includes all partnered women aged 18-45 between 2001 and 2005. For both, employment and participation, the number of observations for treated "Before" are 28,862 and "After" are 43,536. For the control group, the number of observations are 118,753 and 169,823, respectively. One asterisk indicates significance at the ten-percent level, two indicate five percent and three, one percent. 